\title{
La carne y el pescado en el sistema alimentario judío en la España medieval
}

\author{
EnRIQUE CANTERA MONTENEGRo \\ UNED
}

\begin{abstract}
RESUMEN
En este trabajo se ofrece una panorámica general acerca de la carne y el pescado como elementos fundamentales de la alimentación de los judios en la España medieval.

Para ello, se tratan diversas cuestiones, como las prescripciones alimentarias que la religión judía impone en relación con la carne y el

pescado, el lugar que dichos

alimentos ocupaban en la alimentación cotidiana de los judíos hispanos, y la organización pública de la alimentación en las comunidades hispanohebreas de época medieval en cuanto afecta a la carne y al pescado.

\section{PALABRAS CLAVE}

Carne, pescado, kashrut, kasher, animales puros, animales impuros, shehitah, hamín o adafina, avituallamiento, mercado, carnicería.
\end{abstract}

\author{
ABSTRACT \\ This work is a general description \\ about the meat and the fish, as \\ fundamental elements of the jewish \\ meal during the spanish Middle \\ Ages. For that purpose, several \\ questions are dealt, such as the food \\ prescriptions that jewish religion \\ imposes in relation to the meat and \\ the fish; the rol that these food \\ played in the daily meal of the \\ spanish jewish, and the public \\ organization of the food stuffs \\ concernig the meat and the fish, in \\ the spanish hebraic community \\ during the Middle Ages.
}

\section{KEYWORDS}

Meat, fish, kashrut, kasher, pure animals, impure animals, shehitah, hamin or adafina, provisioning, market, butcher's shop.

\section{INTRODUCCIÓN}

Cualquier aproximación al estudio de la alimentación en el mundo judío medieval debe prestar atención a distintas facetas, que son el resultado más evidente de la especificidad de la minoría hebrea en el seno de la sociedad mayoritaria en la que se insertaba. Esta especificidad tiene su fundamento, principalmente, en la religión, por lo que uno de los aspectos más interesantes es, sin duda alguna, el análisis de la normativa de base religiosa que re- 
gula de forma detallada el consumo de alimentos por los judíos, y que ha permanecido prácticamente inalterable desde los tiempos bíblicos hasta la actualidad.

Más allá de su prioritaria finalidad subsistencial, la alimentación tuvo también entre los judíos de la Edad Media importantes connotaciones socio-culturales y religiosas, lo que contribuye a incrementar el interés por esta faceta de la vida cotidiana, al introducir características específicas con relación a las costumbres de las poblaciones cristiana o musulmana con las que convivían, y que contribuian a la singularización de la minoría hebrea.

No obstante, el peso fundamental que en los hábitos alimentarios de los judios ha tenido siempre la religión, a lo largo de toda la Historia, no es óbice para que en el seno de la comunidad hebrea se manifiesten peculiaridades y matices diferenciadores en las prácticas alimentarias entre grupos humanos establecidos en diferentes áreas espaciales, que tienen mucho que ver con los condicionamientos geográficos y con la influencia socio-cultural de los pueblos vecinos. Estas diferencias son particularmente notorias, por ejemplo, entre las comunidades judías sefardíes y las ashkenazies, como resultado de la adaptación a realidades tan dispares como son el ámbito mediterráneo y la Europa centro-oriental, así como también por la poderosa influencia que la tradición islámica tuvo sobre el mundo sefardi en su conjunto.

La coexistencia de los sefardíes con cristianos y musulmanes facilitó el intercambio de costumbres y prácticas folclóricas, y un enriquecimiento de la cultura en general y de las tradiciones culinarias en particular. De este modo, los judíos tomaron prestados múltiples conocimientos de los pueblos con los que convivieron, haciendo también, a su vez, aportaciones notables a la cocina y al folclore mediterráneos. Del mismo modo, las prescripciones religiosas judias obligaron a los sefardíes a adaptar algunas de las recetas de los pueblos con los que convivían, y les llevó a perfeccionar algunas técnicas de preparación de los alimentos, como el braseado o el guiso a fuego lento.

No son muy abundantes las noticias que la documentación medieval ha transmitido en relación con las costumbres alimentarias de los judios españoles. Entre las diversas fuentes documentales disponibles, los procesos inquisitoriales de fines del siglo XV y de los primeros decenios del XVI son, sin duda alguna, las que ofrecen una información más abundante y variada en relación con las creencias religiosas y las costumbres culturales y antropológicas de los judíos, y en muchos casos hacen referencia, más o menos explícita, a la alimentación y al ceremonial que la acompaña. Asimismo, la tradición culinaria hispanohebrea de época medieval tuvo su continuidad en las comunidades sefardíes establecidas desde fines del siglo XV a lo largo y ancho del Mediterráneo, que la han conservado, sin grandes alteraciones, hasta tiempos recientes, lo que ha contribuido también a su mejor conocimiento. 
En la actualidad la cocina judía, marcada por los principios inalterables del kashrut', aunque no menos por un proceso de internacionalización que se impone en los más diversos órdenes de la vida, constituye una de las tradiciones culinarias más variadas y sugerentes.

\section{LAS PRESCRIPCIONES ALIMENTARIAS DE LA RELIGIÓN JUDIA EN RELACIÓN CON LA CARNE Y EL PESCADO}

\subsection{El kashrut o codificación de las leyes dietéticas judias.}

A la hora de preparar los alimentos, los judíos deben atender a las múltiples y complejas prescripciones fijadas por la religión judía, que tienen su fundamento en la halakah ${ }^{2}$, es decir en las secciones de contenido más propiamente jurídico del Talmud y, en particular, en la codificación de las llamadas leyes kashrut.

El kashrut, o compendio de leyes dietéticas judías, tiene su fundamento en los capítulos XI del Levítico y XIV del Deuteronomio, así como en el Talmud y en otros diversos códigos de la Ley rabínica. Pese a su uniformidad básica, existen algunos matices diferenciadores entre las prácticas del kashrut ashkenazí y las del sefardí, que obedecen a distintas tradiciones o costumbres locales.

La prohibición para los judíos de consumir un alimento puede obedecer a motivaciones de muy distinta naturaleza: a que no se hubiera detraído el diezmo para el Templo (en la Antigüedad bíblica); a su supuesta relación con el culto idolátrico; a su procedencia ilícita por robo; a su carácter hamez ${ }^{3}$ durante la Pascua; a que se tratara de un animal impuro; 0 a que, pese a ser animal puro, no hubiera sido degollado con arreglo a las leyes de la halakah.

Las prescripciones alimentarias son tan minuciosas en la religión judia que son muchos los autores que se han esforzado por explicar las razones justificativas de las mismas, más allá de las propiamente religiosas. Para unos serían razones de índole higiénica, en relación con antiguos tabúes, las que moverían a los judios a rechazar el consumo de determinadas especies animales. Para otros, las abstinencias alimentarias favorecerian la conducta moral humana, por la supuesta influencia de la alimentación sobre el Torah.

Idoneidad ritual, en particular por lo que se refiere a las prescripciones alimentarias detalladas en la

Término hebreo que significa, textualmente, "camino" o "marcha". Con él se designan las secciones del Talmud con un contenido más jurídico, y que constituyen un "corpus" de normas y formas de conducta ético-jurídicas. Asimismo sirve para designar la decisión final de un rabi acerca de normas controvertidas de conducta, basada en la tradición o en otros diversos argumentos.

Alimento fermentado, en particular el pan con levadura, cuyo consumo está terminantemente prohibido para los judios durante los ocho días de celebración de la Pascua (Pésah). 
alma y los intelectos del hombre ${ }^{4}$. Para un tercer grupo de autores, las prescripciones alimentarias obedecerían a razones de carácter psicológico-social, como la repugnancia que produciría el consumo de ciertas especies - el cerdo, la anguila - o el temor de que el consumo de determinados alimentos - la sangre - diera lugar a la afloración de instintos crueles. Para otros autores serían razones de carácter dualista, de forma que se atribuiría a las especies animales prohibidas la posesión de espíritus malignos, que se transmitirían a los hombres que las consumieran. Y, por último, otros autores apuntan explicaciones de índole estructuralista, de forma que las prescripciones alimentarias obedecerían a una voluntad decidida de diferenciación con respecto a los pueblos vecinos, con el fin de garantizar su propia identidad ${ }^{5}$.

\subsection{Alimentos puros e impuros.}

Las leyes kashrut afectan sólo al consumo de productos de origen animal, de forma que todos los alimentos vegetales tienen la consideración de kasher, es decir de aptos para el consumo por los judíos ${ }^{6}$. Quizá por este motivo la tradición judía ha considerado siempre el vegetarianismo como un estilo de vida ideal, aunque no sea algo propiamente requerido por la Ley. Se trataría de una práctica que, como la de los ayunos voluntarios practicados por los judíos más piadosos - generalmente los lunes y los jueves-o la abstinencia en el consumo de bebidas alcohólicas, ayudaría a progresar en el camino de la perfección espiritual.

No obstante, y pese al importante lugar que los productos de origen vegetal ocupan en la alimentación cotidiana judía, desde la Antigüedad hasta los tiempos actuales, son muy pocos los judíos que siguen un régimen vegetariano estricto. Sólo en determinadas épocas del año, como en las tres semanas que preceden al ayuno de tish a be-av o durante el período de luto de siete dias que acompaña el fallecimiento de un pariente próximo (shibbah) ${ }^{8}$, la abstinencia de carne, que no de pescado, estaba más generalizada.

- Asi, la Torah (Éxodo, XXII, 30; Levitico, XI, 44-45; Deuteronomio. XIV, 21) asocia la legislación alimentaria con el concepto de santidad.

Teresa de CASTRO MARTinez, La alimentación en las crónicas castellanas bajomedievales. Universidad de Granada, 1996, págs. 183-184

"Kasher es un término hebreo que significa "apto" o «licito". Con él se hace referencia a los alimen tos (carne, pescado, queso, vino) que son aptos para el consumo por los judios, de acuerdo con las prescripciones de la Torah.

Festividad del calendario litúrgico judio que se celebra el día 9 del mes de av (julio/agosto). Es un dia de duelo profundo, en el que los judios deben guardar un riguroso ayuno en recuerdo de la destrucción del primer Templo de Jerusalén por Nabucodonosor (586 a.C.) y del segundo por Tito (70 d.C.).

Shibbah se denomina al periodo de luto riguroso que comprende los siete dias siguientes al fallecimiento de un familiar próximo. En época medieval, los parientes más cercanos del difunto (córyyge, padres, hijos, hermanos) permanecian durante este tiempo la mayor parte del dia en casa, y no realizaban ninguna actividad; permanecían sentados en el suelo sobre almohadones o sobre pequeños taburetes, con trecuencia detrás de la puerta principal de la casa, vestian trajes negros y calzaban alpargatas. 
Por lo que respecta a los mamíferos, la diferenciación entre animales puros (tahor) e impuros (tame) es clara. Para que sea considerado animal puro, todo cuadrúpedo debe estar dotado de pata ungulada - con casco o pezuña-, tener pezuñas hendidas o divididas en dos dedos, y ser rumiante; la falta de uno cualquiera de estos requisitos convierte al animal en impuro. El Deuteronomio (XIV, 4-8) es explícito al respecto:

«Estos son los animales que podéis comer: cualquier vacuno, cualquier ovino y cualquier caprino; el ciervo, la gacela, el corzo, la cabra montés, el antílope, el búfalo, la gamuza, o sea todo animal que tenga la pezuña dividida (partida) y rumie. Pero no comeréis los que rumien y no tengan la pezuña hendida, como el camello, la liebre y el conejo. Impuros son para vosotros. Tampoco comeréis los que tengan pezuña partida pero no rumien, como el cerdo. No comeréis su carne ni tocaréis su cuerpo muerto".

Los animales impuros transmiten su impureza a cuanto entra en contacto con ellos, tanto a las fuentes y vasijas en las que se depositen y a las mesas que soporten esos recipientes, como a los vestidos que entren en contacto con dichos alimentos. No obstante, las prohibiciones relativas al consumo y manipulación de determinadas especies animales varian desde las que obligan a su destrucción hasta las que, a pesar de su impureza, permiten su manipulación y trato comercial. En este sentido, en una responsa ${ }^{9}$ dirigida a la aljama judía de Murcia, Shelomoh ibn Adret de Barcelona ${ }^{10}$ considera lícita la compraventa de la piel de animales no aptos para el consumo, considerando que las prohibiciones sólo hacen referencia al consumo de su carne ${ }^{11}$.

Pero además de proceder de animal puro, para que la carne sea considerada kasher, el animal no debe presentar ninguna tara ilegal, como órganos externos o internos defectuosos ${ }^{12}$. Es muy expresiva a este respecto la explicación que da un rabino anónimo ante el tribunal de la Inquisición:

El luto se expresaba también en la comida, muy frugal durante esos dias. Conocida entre los judios sefardies como cohuerzo, consistía en pescado, huevos cocidos, verduras, legumbres, fruta y pan, consumiéndose en una mesa baja, sentados en el suelo; la ingestión de carne estaba rigurosamente prohibida, y entre los más ortodoxos el cohuerzo podia quedar reducido sólo al consumo de ovolácteos.

En hebreo sheelot u-teshubot (= preguntas y respuestas). Se denomina asi a las respuestas que a comienzos de la Edad Media daban las escuelas superiores rabinicas de Babilonia y Palestina a las cuestiones que se les formulaban desde las más diversas comunidades hebreas de la diáspora. Con posteriori dad. y hasta el momento actual. esta función compete a las autoridades halákicas. Las colecciones de responsa son, aún en la actualidad, un instrumento fundamental en materia de halakah.

Nacido alrededor del año 1235 en Barcelona y muerto en 1310. Shelomoh ben Abraham ben Adret es una de las figuras más destacadas de la Sefarad de finc's del siglo XIIl y comienzos del XIV. Discipulo y sucesor de Mosheh ben Nahmán (Nahmánides), gozó de una indiscutible autoridad en Derecho Romano y rabinico, siendo autor de unas once mil Responsa.

Norman Roth, "Los judios murcianos desde el reinado de Alfonso $X$ al de Enrique II", en Miscelánea Medieval Murciana, XV (1989), págs. 27-51 (en concreto, pág. 29).

El Talmud, en su tratado Hullin (43 a), clasifica los defectos que pueden presentar los animales en ocho categorias: nevukah o perforación de la pared de los órganos internos; pesukah o rotura de alguna conducción; netulah o ausencia de algún miembro; haserah o defecto orgánico; keru'ah o desgarro de las 
“... La carne terefá ${ }^{13}$ es cuando la res tiene pegada una tela al liviano ${ }^{14}$ en el costado de las reses; y significa que era mandamiento en la Ley judaica que no comiesen carne muerta, y así no la comian, ni res que tuviera sangre en el cuerpo, porque la res mortecina siempre acostumbra de tener sangre en el cuerpo ${ }^{15}$.

Asimismo, en los procesos inquisitoriales de fines del siglo $\mathrm{XV}$ y de los primeros decenios del XVI se encuentran con cierta frecuencia referencias a judaizantes que desechaban animales por presentar algún defecto. Así, en la testificación que en 1505 hizo ante el tribunal de la Inquisición Juan, pescador vecino de Almazán, afirmó

“... que viviendo en Oradero ${ }^{16}$ con Álvaro de Luna e Garçía Laynez e Enrique, que está agora en Alcalá de Henares, christianos nuevos, trayán a vender una gallina e estava un poco lysiada, e dixeron a su moço los susodichos que non la conprase ${ }^{17}$.

Por otra parte, el animal debe ser sacrificado conforme al complejo ritual judío conocido como shehitah, minuciosamente reglamentado en el Talmud, si bien su existencia se encuentra ya implícita en la Torah (Deuteronomio, XII, 21). La shehitah consiste, básicamente, en el degollamiento del animal mediante un corte único en el cuello que seccione a un tiempo la traquea, el esófago y la yugular; para ello ha de emplearse un cuchillo cuya hoja, plana y muy afilada, no debe presentar ningún tipo de mella, sin duda con el fin de favorecer el más rápido desangrado del animal y evitarle un sufrimiento innecesario. Por este motivo, el degollamiento va siempre precedido de la comprobación de la hoja del cuchillo, así como de la recitación de una bendición.

membranas o paredes de los órganos internos; derusah o presencia de sustancias nocivas introducidas en el cuerpo del animal; nefulah o muerte fulgurante; y shevurah o fractura ósea (Miguel Ángel Motis Dolader, "Régimen alimentario de las comunidades judias y conversas en la Corona de Aragón en la Edad Media", en Colloqui d'Historia de l'Alimentació a la Corona d'Aragó. Lleida. Institut d'Estudis llerdencs, 1995, págs. 205-361 (en concreto, pág. 327).

${ }_{13}$ Terefah es un término hebreo que significa, literalmente, "despedazado". Con él se hace referencia a la carne del animal que ha sufrido un desgarro o un daño importante, asi como a la que no ha quedado totalmente desangrada y que, por tanto, no resulta apta para el consumo por parte de los judios. Por extensión, se denomina terefah - trifá entre los judíos españoles de época medieval- a todo alimento que no es apto para el consumo por los judíos en virtud de las prescripciones alimentarias contenidas en la Torah y en el Talmud; es, por tanto, el término contrapuesto a kasher.

14 Es decir, cuando tenía la pleura inflamada.

"Jaume RIERA I SANS, "La conflictivitat de l'alimentació dels jueus medievals (segles XII-XV)", en Alimentació i societat a la Catalunya medieval. Barcelona. C.S.I.C., 1988, págs. 295-311 (en concreto, pág. 305).

Actual despoblado, situado en las proximidades de la localidad soriana de Langa de Duero.

'Archivo Diocesano de Cuenca (en adelante, A.D.C.), Inquisición, leg. 748/8, fol. 3v. Carlos CARRETE Parrondo - Carolina Fraile Conde, Fontes ludaeorum Regni Castellae. IV. Los judeoconversos de Almazán, 1501-1505. Origen familiar de los Lainez. Salamanca. Universidad Pontificia de Salamanca Universidad de Granada, 1987, págs. 90-91. 
La complejidad del ritual de la shehitah obligaba a que todas las comunidades hebreas de cierta importancia dispusieran de un matadero-carnicería propio donde el shoet (matarife-carnicero contratado por la comunidad) sacrificaba los animales que, posteriormente, eran examinados minuciosamente, mediante la bediqa $h^{18}$, por otro funcionario de la aljama, el bodeq. En algunos procesos inquisitoriales se contienen alusiones indirectas a la práctica de la bediqah por algunos judaizantes tras haber sacrificado un animal; así se deduce, por ejemplo, de la declaración de Alonso Ordóñez, vecino de la localidad burgalesa de Hontoria de Valdearados, quien el día 3 de enero de 1502 declaró ante el tribunal de la Inquisición que un día, en compañía de Alonso Núñez de Santafé, cristiano nuevo, y Barahona, escudero del conde de Coruña, compró una cabrita,

“... e después de conprada... Alonso Núñez la degolló e desolló, porque avía sido carniçero quando judio, e la avian de partyr la... cabrita. E después de desollada.... Alonso Núñez la cató e miró, e dixo que no quería della. E este testigo e... Barahona dixeron que porque estava trefé la dexava. E asý dieron su parte de Alonso Núñez a uno que se llamava Córdova» ${ }^{19}$.

Los amplios conocimientos acerca de la Ley religiosa judía que requiere el ejercicio del oficio de shoet motivó que, con frecuencia, fueran designados para su desempeño rabinos con estudios especializados, y que se redactaran guías con el fin de facilitar su trabajo. En el caso de que el aspirante a shoet no fuera rabino, se le obligaba a seguir unos estudios específicos, sometiéndole luego a un examen acerca de las normas de la shehitah.

Los judeoconversos que cumplían en secreto con la religión judía se abastecian habitualmente de carne en la carnicería de la judería, o recurrian a algún judío o judeoconverso experto en la shehitah para que les sacrificara los animales para el consumo familiar. En Ciudad Real, a fines del siglo XV, eran varios los judeoconversos que hacían las veces de carniceros para la numerosa comunidad judeoconversa de esta localidad; entre ellos figura García Barbas, sastre de profesión, quien, según la declaración que Antón López hizo ante el tribunal de la Inquisición,

" Examen ritual del animal, antes y después del sacrificio, con el fin de comprobar que no presenta ninguna tara que lo convierta en no apto para el consumo por los judíos.

${ }_{14}$ Archivo General de Simancas (en adelante, A.G.S.), Patronato Real, Inquisición, leg. 28/73, fol. 1.091v. Carlos Carre IE Parrondo, Fontes ludaeorum Regni Castellae. II. El Tribunal de la Inquisición en el Obispado de Soria (1486-1502). Salamanca. Universidad Pontificia de Salamanca - Universidad de Granada, 1985 , págs. $140-141$. 
«... era como rabí, porque mataba carne para los confesos; e vido mucha vezes que le llamaban para matar la carne, y que él yva allá, y quando venía preguntávale Juan Diaz, trapero, que tenía tienda frontero, que sy le dexaba alguna carne de aquella que avía muerto" ${ }^{20}$.

Otro vecino de Ciudad Real que actuaba como carnicero para los judeoconversos era Juan González Escogido, quien fue procesado por el tribunal de la Inquisición en los años 1484-1485. Varios testigos presentados por el promotor fiscal declararon en su proceso que veían a muchos judeoconversos acudir a su casa para llevarse carne. Entre estos testigos, Lope González, escudero, manifestó que

"... sabe e vido que llevavan muchas vezes a su casa aves ha degollar, e que oyó dezir que era rabí de los confesos" 21 .

En otras ocasiones los judeoconversos recurrian a algún conocido judio para que les sacrificara los animales para el consumo familiar. Éste es el caso que denuncia María Ruiz, criada de Diego Díaz, especiero vecino de Ciudad Real, quien afirmó ante el tribunal de la Inquisición

“... que vio venir muchas vezes allí, a casa de su amo Diego Díaz, un judío que les mataba la carne que abian de comer, e dezían ellos a este testigo que porque era más saborosa la carne traýan allí aquel judío. E que vido venir alli por carne a Juan Díaz, trapero, e a otros conversos" ${ }^{22}$.

Parecido es el caso del judeoconverso Juan Rodríguez, escribano de número de la ciudad de Soria, quien con frecuencia recibía en su casa carneros, cabritos y ansarones sacrificados en casa del judío soriano Lezar Caballero; al recibirlos decía a quien le hacía entrega de los mismos:

"... Dezidle a don Lezar que muchas graçias, que yo lo pagaré en buenas obras e que me aya por encomendado, pues que sabe que no como otra carne syno la quél me enbía. E que vido que... Juan Rodríguez estava en fama de no comer otra carne salvo de lo que de casa de... don Lezar le enbiavan o de lo quél mismo se degollava por sus manos" ${ }^{23}$.

\footnotetext{
20 Proceso inquisitorial contra Juan Díaz, alias Juan Dinela, trapero (1484-1485). Archivo Histórico Nacional (en adelante, A.H.N.), Inquisición de Toledo, leg. 143, n. ${ }^{0} 4$, fol. $3 \mathrm{v}$. Haim BEINART, Records of the Trials of the Spanish Inquisition in Ciudad Real. Jerusalem. Israel National Academy of Sciences and Humanities, 1974-1985, 4 vols. (en concreto, vol. 1, pág. 574).

Proceso inquisitorial contra Juan González Escogido (1484-1485). A.H.N., Inq. Toledo, leg. 154, n.? 13, fols. 4v-5v. H. Beinart, Records, vol. I, págs. 498-501.

$2:$ Proceso inquisitorial contra Juan Diaz, alias Juan Dinela, trapero (1484-1485). A.H.N., Inq. Toledo, leg. 143, n. ${ }^{\circ} 4$, tol. 3v. H. BEInART, Records, vol. I, pág. 575.

${ }^{23}$ A.G.S., Patronato Real, Inquisición, leg. 28/73, fol. 1098r. C. Carrete, Fontes ludaeorum Regni Castellae, II, pág. 151.
} 
Por otra parte, y debido a la prohibición bíblica de consumir sangre ${ }^{24}$, los animales sacrificados para el consumo humano deben quedar totalmente desangrados; a este fin, tras su degollamiento, los colgaban por las patas traseras, boca abajo, para que la sangre fluyera más fácilmente. El desangrado de los animales era un arte en el que se manifestaba la mayor o menor pericia del carnicero judío. Particularmente habilidoso debía ser a estos efectos un judío vecino de Huete, arrendador de profesión, a quien Fernando de la Barrera, cura de la localidad conquense de Villar del Saz de Navalón, hacía degollar los animales para su consumo porque

\section{«... decía que no avía tal carne como la que mataba el judio, porque la desangraba bien» 25 .}

Posteriormente, al preparar la carne para su consumo, es habitual que se remojara varias veces en agua fría durante al menos media hora y que se dejara secar con sal durante otra hora, con el fin de que quedara totalmente seca de sangre. Así, en la documentación inquisitorial de fines de la Edad Media y de los primeros tiempos de la Modernidad se encuentran abundantes referencias al lavado meticuloso de la carne por parte de mujeres judeoconversas acusadas de judaizar. Es muy expresiva la declaración de Magdalena, mujer de Martín Ximón, vecina de San Andrés, tierra de la localidad alcarreña de Jadraque, quien, en el proceso seguido contra su ama Isabel López, afirmó que la procesada y Mari López

“... mandavan a este testigo que lavase mucho la carne, con dos o tres aguas, hasta que la carne saliese blanca e el agua clara» ${ }^{26}$.

Otra sirvienta, llamada María, vecina de la localidad soriana de Aguaviva de la Vega, declaró que su ama Angelina, mujer de Cristóbal de León, cristianos nuevos vecinos de Almazán, cuando llevaba carne a casa

«... le mandava algunas vezes... que la lavase..., e después de lavada le echava sal... e la ponía en una çestilla... e la colgava..., la quitava de allí e la echava en la olla a cozer ${ }^{27}$.

\footnotetext{
:4 Asi se prescribe en Génesis, IX, 4, y en Levitico, XVII, 10-14 y XIX, 26.

A.G.S., Patronato Real, Inquisición, leg. 28/73, fol. 1105v. C. CARRETE, Fontes ludaeorum Regni Castellae, vol. II, pág. 163.

it Proceso inquisitorial contra Isabel López, mujer de Francisco de Murcia, tendero vecino de la localidad alcarreña de Cogolludo (1516-1518). A.H.N., Inq. Toledo, leg. 162, n. ${ }^{\circ} 6$, fol. 11 v. Renée C. LEVINE, Women in Spanish Crypto-Judaism, 1492-1520. University Microtilms International. Ann Arbor, Michigan, 1986, pág. 355.

A.D.C., Inquisición, leg. 749/15, fol. 22r-v. C. CARRete - C. Fralke, Fontes ludaeorum Regni Casiellae, vol. IV, pág. 32.
} 
De igual modo, y en memoria de la lucha del patriarca Jacob con el ángel narrada en el capítulo XXXII del Génesis, los judíos deben retirar el nervio ciático que se encuentra en la articulación del muslo y toda la grasa adherida a él; este nervio, denominado en hebreo gid hanasheh (= nervio oculto), era popularmente conocido entre los judíos españoles como landrecilla o glandolica; en ocasiones quitaban también el hueso próximo al nervio ciáti$\mathrm{co}$, al que la documentación medieval denomina «anqueta» 0 "anguilla». En el proceso inquisitorial seguido contra María Rodríguez, judeoconversa vecina de la localidad soriana de Berlanga de Duero, en septiembre de 1543 testificó Pedro Rodríguez, quien manifestó

«... que a la dicha Mari Rodríguez le vido sacar las dichas landrezillas estando presentes las dichas personas, que por lo menos fueron dos o tres vezes. Y la dicha landrezilla le paresçe que sería de la manera de la carne de una molleja de abe, que no se sabe determinar en ella porque sacándola la dicha Mari Rodriguez la arrojava luego. Y que de las dichas piernas las sacava de la pared de abaxo dellas, donde estava el huesso de la anguilla» ${ }^{28}$.

Es también curiosa la descripción que de la operación de retirada de la landrecilla hace Juana, criada de Íñigo López de Ayala y de su mujer María Hermosa, cristianos nuevos vecinos de Almazán, cuando declara ante el tribunal de la Inquisición

“... que todas las vezes que trayan pierna de carnero de la carneçeria vio este testigo cómo Ynés, donzella, fija de Yñigo López e María Hermosa..., ques de más de veynte años, fendía las dichas piernas por medio y las sacava la landrezilla y la echava, la qual estava en medio de la pierna, ques redonda, como negrilla; y este testigo le dezía que por qué la sacava y la echava, y la susodicha dezía... que porque non hera buena. Lo qual le vido este testigo fazer cada vez que trayan piernas $^{29}$.

Asimismo, y obedeciendo el mandato divino contenido en la Torah,

"Y le dijo el Eterno a Moisés: Diles a los hijos de Israel: No comeréis grasa de vacuno, ni de ovino, ni de caprino. Y la grasa de cadáver de animal y de animal desgarrado la usaréis para toda labor, pero no podrá comerse. Todo el que comiere grasa de animal presentado para ofrenda ignea será extirpado de"su pueblo". (Levítico VII, 22-25),

: Proceso inquisitorial contra María Rodríguez, mujer de Pedro Rodríguez, vecina de Berlanga de Duero (1526-1528; 1547). A.D.C., Inquisición, leg. 101/1448. Ricardo MuNOz SOLLA, Los conversos jupaizantes de Berlanga de Duero (s. XV-XVI). Tesis Doctoral. Universidad de Salamanca, 2003, vol. III, págs. 882-883.

${ }^{29}$ A.D.C., Inquisición, leg. 748/5-5, fol. 31v. C. CARRETE - C- FrallE, Fontes ludaeorum Regni Castellae, vol. IV, pág. 85 . 
los judíos de época medieval retiraban con sumo cuidado toda la grasa (helev) adherida a la carne de los animales y echaban una pequeña porción de ella al fuego; esta operación, denominada en hebreo nikkur, es conocida popularmente entre los judios y judeoconversos españoles como "purgación de la carne" 30 .

Son muy frecuentes las referencias que en procesos inquisitoriales de fines del siglo XV y de los primeros decenios del XVI se hacen acerca de judeoconversos que retiraban de la carne toda la grasa adherida a ella. Así Catalina, sirvienta de Martín García de la Fuente y de su mujer María García, cristianos nuevos vecinos de Almazán, declaró ante el tribunal de la Inquisición que había visto algunas veces a su ama

"... quitar el sebo a la carne cuando trahe reñonada ${ }^{31}$ o mucho sebo, por mandado de su amo; e lo quitó con las uñas, e algunas vezes lo echa a los gatos, e otras vezes refriega los çapatos con ello" ${ }^{32}$.

El "purgado" de la carne por judíos y judaizantes era tan minucioso que, como refiere la documentación, quedaba toda como "pellizcada". Juana de Fuente Alvilla, vecina de Almazán, declaró en junio de 1505 ante el tribunal de la Inquisición que en una ocasión había llevado carne a la mujer de Ruy Díaz, también vecina de Almazán

«... y que la dio sana e del lomo del quarto çaguero, y que después ge la tornó la hermana de... la mujer de Ruy Diaz, que se llama Ynés, muger de Diego Laynez, pellizcada, quitada el sevo de una parte e de otra, y que este testigo le dixo: ¿Qué diablo ha andado con esta carne? Divosla sana e florida, y tráesmela pizcada, que paresçe que pollos o ratones lo han comido $e$ picado ${ }^{33}$.

Por esta razón, judíos y judeoconversos preferían la carne procedente de partes del animal con menor concentración de grasa. Así Magdalena, vecina de la localidad soriana de Velacha, declaró ante el tribunal de la Inquisición que durante el tiempo en que había servido en casa de Pedro Lainez y de su mujer Aldonza, cuando había de traerse carne de la carniceria, le decía a ella o al mozo o moza que iba a buscarla

\footnotetext{
30 Joseph Nehama - Jesús Cantera, Dictionnaire du Judéo-Espagnol. Madrid. Consejo Superior de Investigaciones Científicas, 1977, pág. 458, voz "purgár".

"Carne procedente de la región lumbar del animal, próxima a los riñones.

32 A.D.C., Inquisición, leg. 748, 5-6, fol. 29r. C. CARRETE - C. Fraile, Fontes ludaeorum Regni Castelląe, vol. IV, pág. 50 .

${ }^{3}$ A.D.C., Inquisición, leg. 749/15, fol. 4v. C. CaARETE - C. FraIle, Fontes ludaeorum Regni Castellae, vol. IV, pág. 35 .
} 
"... que no truxese del lomo y de la riñonada ni de cabo (= parte) que toviese mucha gordura, salvo de agujas o espalda o pierna» ${ }^{34}$

En definitiva, judios y judaizantes comían la carne totalmente seca de sangre y sin el menor resto de grasa. Así lo especifica Francisca, mujer de Pedro el herrero, vecina de Almazán, quien declaró ante el tribunal de la Inquisición que cuando llevaba carne a casa de sus amos maestre Bernal y María Álvarez, cristianos nuevos vecinos de Almazán, su ama le hacía quitar con las uñas todo el sebo y la gordura, y luego

«... se lo fazía lavar con çinco o seis aguas fasta que todo quedava magro, como carne blancuzca, mortezina; e fecho esto, lo echava ella en la olla, y con ello echava garvancos e çebollas y espeçias, e cozía fasta que todo estava desfecho, como formigos $^{35}$, y se lo comían ${ }^{36}$.

La prohibición de consumir grasa de animal vacuno, ovino y caprino llevaba a los judios y judaizantes a un rechazo radical del tocino, lo que constituía para los inquisidores, y para los cristianos viejos en general, una señal inequívoca de judaísmo. La aversión al tocino llegaba hasta el extremo de que no consentían comer en un plato que con anterioridad hubiera contenido alimentos cocinados con tocino, o que los cubiertos empleados en una olla en la que se cocinaba con tocino fueran introducidos en la olla donde se cocinaban sus alimentos. Es esto lo que se deduce de la testificación de Juana, mujer de Sebastián Rodrigo, vecina de la localidad soriana de Centenera, quien declaró ante el tribunal de la Inquisición que cuando servía en casa de Fernando Laínez y de su mujer Ana, judeoconversos vecinos de Almazán, un día que ella y Catalina, criada también del matrimonio Laínez, estaban cocinando con tocino,

«... vido este testigo cómo (su ama) se puso la toca delante de las narices por el olor del toçino, porque... su ama dixo: Ese güesmo (= olor) dese toçino se me entra en la garganta adelante. E vido... que para sus amos se fazía olla aparte. syn toçino; e para este testigo e los otros moços e moças de casa se fazía olla aparte, con toçino e çeçina. $Y$ no dexava... su ama a este testigo nin a la otra moça que la cuchara que entrava en la olla... de sus amos entrase en la de los moços, ni la de los moços en la de sus amos" 37 .

iA A.D.C., Inquisición, leg. 749/15, fol. 12r. C. Carrete - C. Fraile, Fontes ludaeorum Regni Castellae, vol. IV, págs. 22-23.

"Los "formigos" $u$ "hormiguillos" es un plato a base de pan desmenuzado, parecido en cierto modo al alcuzcuz árabe. Entre los judios sefardies consistia en una especie de sopa de almendras machacadas con leche (C. Carrete - C. Fraile, Fontes ludaeorum Regni Castellae, vol. IV, pág. 27).

36. A.D.C., Inquisición, leg. 748/5-6. fols. 34v-35r. C. CarRete - C. Fralle, Fontes ludaeorum Regni Castellae, vol. IV, pág. 27.

A.D.C., Inquisición, leg. 748/5-6, fol. 32 v‥ C. Carrete - C. Fralle, Fontes ludaeorum Regni Castellae, vol. IV, pág. 66 . 
Algo parecido es lo que afirma Lope García, cristiano nuevo vecino de Almazán, quien declaró ante el tribunal de la Inquisición que su mujer Graciana

«... no come toçino ni de la vianda que con ello se guisa, porque algunas vezes lo a visto; e que en la olla que ay toçino, sy meten una cuchara en ella, no lo consiente meter en la olla que se guisa para ella. E que los platos e escudillas en que cahe toçino no come en ellos fasta que los frieguen e alinpien " ${ }^{38}$.

No obstante, y debido al temor a las delaciones, se imponía la prudencia, por lo que los judeoconversos que no comían tocino se esforzaban para que no lo notaran sus criados, alegando con frecuencia que su rechazo del tocino obedecía a que les iba mal para el estómago (“les fazía mal»). Así Graciana de Santa Cruz, mujer de Lope García, vecina de Almazán, declaraba que su hija Isabel, aún después de haberse convertido al cristianismo

«... no come toçino ni de la vianda que con ello se guisa; $y$ si la cuchara meten en la olla donde se guisa con toçino no consiente que se meta en la olla que se guisa para ella aparte... E que sabe que su estómago non lo lleva, porque luego como se tornó christiana le dieron a comer toçino, e le fizo mal, e lo echó del estómago " 39.

Por lo que se refiere a las vísceras de los animales, los judíos no consumen el estómago ni los intestinos, pero sí el hígado, los riñones o el corazón, aunque para que sean alimentos kasher deben estar totalmente secos de sangre. Por este motivo era habitual que consumieran estos órganos asados a la parrilla o a la brasa, con el fin de que la carne quedara limpia de sangre. Todavía en la actualidad, uno de los platos más típicos de la cocina sefardí es el hígado de pollo o de oca picado, servido normalmente sobre rebanadas de pan.

Por otra parte, los judíos tienen terminantemente prohibida la mezcla de productos cárnicos y lácteos, en virtud de la prescripción divina contenida en el Levítico (XXIII, 19):

"Los primeros frutos de tu campo los traerás a la casa del Eterno, tu Dios. No cocinarás cabrito en la leche de su madre».

y en el Deuteronomio (XIV, 21):

"No comeréis ningún cuerpo muerto naturalmente. Lo darás al forastero que resida en tus ciudades para que lo coma o lo venderás a un extranjero, por cuanto tú (oh Israel) eres un pueblo consagrado al Eterno tu Dios. No cocerás cabrito en la leche de su madre».

38 A.D.C., Inquisición, leg. 748/5-5, fol. $14 v^{9}$. C. Carrete - C. Fralle, Fontes ludaeorum Regni Castellae, pág. 108.

${ }^{24}$ A.D.C., Inquísición, leg. 748/5-6, fol. $13 v^{2}$. C. Carrete - C. Fralle, Fontes ludaeorum Regni Castellae, vol. IV, pág. 108. 
Esta prohibición no sólo afecta al consumo, sino también a la conservación y a la preparación de los alimentos. El Talmud distingue entre tres niveles de prohibición: cocinar carne y leche conjuntamente, consumirlos también juntos, y obtener determinados beneficios de su combinación. También el Talmud fija en seis las horas que deben transcurrir para poder consumir productos lácteos después de haber comido carne; a la inversa, sólo es necesario esperar una hora para comer carne después de ingerir productos lácteos.

Por este motivo, en las casas de judíos observantes fieles de la Ley se dispone, habitualmente, de recipientes y de cubiertos diferentes para los productos cárnicos y para los productos lácteos. La pulcritud es menor con recipientes de cristal, debido a que el vidrio no es material poroso; pero, en cualquier caso, para su uso para productos cárnicos después de haber sido utilizados para productos lácteos, o a la inversa, deben permanecer previamente sumergidos en agua durante al menos 24 horas.

Algunos estudiosos consideran que el origen remoto de esta prescripción se encuentra, probablemente, en el culto fenicio-cananeo, y que su razón última sería evitar todo acto que pudiera entenderse como inhumano ${ }^{40}$. En la actualidad, y al margen de la prescripción propiamente religiosa, algunos judíos no observantes de la Ley guardan también esta tradición, considerando que la mezcla de productos cárnicos y lácteos en la misma comida dificulta la digestión.

Los alimentos considerados "neutros" y que, como tales, pueden ser consumidos de forma indistinta con carne o con leche, son denominados parveh o pareve, y son, básicamente, el pescado, los huevos, la fruta, las verduras, las legumbres y los aceites vegetales.

Debido a que el cuajo que se utiliza para la elaboración del queso se encuentra en el estómago de los rumiantes ${ }^{41}$, la mayoría de los quesos naturales no son kasher, porque en ellos hay mezcla de productos cárnicos y lácteos. No obstante, los judíos disponen de quesos elaborados con algún sustituto del cuajo natural, consistente, normalmente, en algún ácido o encima que propicia la coagulación de la leche $e^{42}$.

Por lo que respecta a las aves, los judíos únicamente tienen prohibido el consumo de una veintena de especies avícolas, que están minuciosamente relacionadas en el Levítico (XI, 13-19) y en el Deuteronomio (XIV, 11-18); se trata de aves de rapiña y carroñeras, así como de las aves acuáticas excepto las anseriformes:

40 Herbert HAAG - A. VAN DEN BORN - Serafín de Ausejo, Diccionario de la Biblia. Barcelona. Editorial Herder, 1964, columnas 1083-1084, voz "Leche".

¿ El cuajo es un fermento que se halla, principalmente, en la mucosa del estómago de los rumiantes hembras durante el período de la lactancia, y que se emplea para coagular la caseína de la leche.

${ }^{42}$ Por este motivo, en la actualidad hay algunos vegetarianos estrictos que sólo consumen quesos kasher judios, ya que el cuajo empleado en ellos es siempre de origen vegetal. 
"Y de las aves no comeréis el águila, el quebrantahuesos y el halieto; el milano, el buitre y (otras aves) de su especie; el cuervo y (otras aves) de su especie; el avestruz, la lechuza, la gaviota, el gavilán y (otras aves) de su especie; el mochuelo, el somormujo y el buho; el cisne, el pelícano y el buitre egipcio; la cigüeña, la garza y (otras aves) de su especie, la abubilla y el murciélago» (Levítico, XI, 13-19).

La prescripción se hace extensiva a todos los animales volátiles, especificándose también los insectos voladores puros e impuros:

«Todo volátil que anda en cuatro patas (insectos) os será detestable, pero podréis comer de tales criaturas si, aparte de sus cuatro patas, tuvieren dos piernas largas para saltar en la tierra. Así, podréis comer la langosta y (otros insectos de) su especie, el sol'am y (otros insectos de) su especie, el saltamontes y (otros insectos de) su especie y el grillo y (otros insectos de) su especie. Los demás volátiles de cuatro patas serán para vosotros abominables. Y por ellos os tornaréis impuros: quien tocare el cuerpo muerto de ellos quedará impuro hasta el atardecer. Si alguien lo hiciere deberá lavar sus vestiduras, (no obstante lo cual) quedará impuro hasta la puesta del sol» (Levítico, XI, 20-25).

Por lo tanto, y al contrario que con los mamíferos y los peces, la Torah no determina las características morfológicas que distinguen las especies de aves puras de las impuras; a falta de estas características morfológicas que las distingan, la tradición debió tener un peso fundamental en la determinación de las especies puras e impuras. En general, son aptas para el consumo por los judíos las aves columbiformes (paloma), galliformes (gallina, perdiz, faisán, pavo), anseriformes (pato, oca, ganso) y pajariformes (gorrión) ${ }^{43}$.

Las aves eran sacrificadas, normalmente, en las propias viviendas, aunque siguiendo también de forma estricta el ritual de la shehitah; así, para que sean kasher, las aves deben ser degolladas, nunca estranguladas. Es muy ilustrativa a este respecto la testificación de Catalina, vecina de Argamasilla y moradora en Ciudad Real, quien en el proceso inquisitorial seguido contra su ama Mayor González, vecina de Ciudad Real, declaró

«... que se acuerda que las aves que se mataban en casa de los dichos sus amos las mandaban degollar, asy las gallinas como pollos e palominos, e que este testigo e la dicha Juana Gonçález las degollavan por mandado de la dicha Mayor Gonçález, su ama. E que sy alguna vez acaeçía que este testigo e la dicha Juana Gonçález ahogavan los palominos torçiéndoles las caveças, que la dicha Mayor Gonçález reñia con este testigo e con la dicha Juana Gonçález, e algunas vezes no comía dellos, diziendo que estava la carne negra ${ }^{44}$, e otras vezes comía, aunque muy poco" ${ }^{45}$.

\footnotetext{
${ }^{43}$ M.A. MOtIS DOLADER, "Régimen alimentario de las comunidades judías y conversas en la Corona de Aragón en la Edad Media", pág. 240.

${ }^{44}$ Es decir, con sangre.

${ }^{45}$ A.H.N., Inquisición de Toledo, leg. $155, \mathrm{n} .97$, fol. 4 vํ. H. BeInART, Records, vol. III, pág. 384.
} 
Una vez degollado el animal, la sangre derramada debe ser cubierta con tierra; en otras ocasiones se recoge en una escudilla llena de tierra, arena o ceniza. El cubrimiento de la sangre de todo animal es una obligación para los judíos que se hace extensiva a cualquier animal, en señal de respeto; la prescripción de la Torah (XVII, 13-14) no deja lugar a ninguna duda:

"Y todo varón de los hijos de Israel y todo forastero que habitare entre ellos que cazare animal o ave que pueda comerse, derramará su sangre y la cubrirá con polvo, porque el alma de toda carne es su sangre, que expía por el alma. Por eso dispuse que nadie de los hijos de Israel coma la sangre de cualquier carne. La vida de toda carne es su sangre: quien la coma será extirpado". (Levítico, XVII, 13-14).

Es muy ilustrativa a este respecto la declaración que hizo ante el tribunal de la Inquisición María Rodríguez, vecina de Almazán, cuando afirma que un día que acudió a casa de Magdalena, mujer de Luis del Peso, cristianos nuevos vecinos de Almazán

"... vido e oyó este testigo a... Madalena que dixo a un fijo suyo que se llama Françisquito, de hedad de diez años: Anda, ve e tráeme un pandero de tierra; e vido cómo... Françisquito lo truxo, e... Madalena tomó el... pandero e cubrió con la... tierra la sangre de un carnero que avian matado en su casa ${ }^{46}$.

Por lo que respecta a los peces, y a los animales acuáticos en general, el Levitico (XI,12) y el Deuteronomio (XIV, 9-10) especifican las características morfológicas que determinan que una especie acuática sea pura o impura:

"De lo que vive en el agua comeréis todo lo que tiene aletas y escamas, y no comeréis lo que no tiene aletas y escamas, porque para vosotros es impuro" (Deuteronomio, XIV, 9-10).

La posterior reglamentación del Talmud obliga a que las especies acuáticas posean dos aletas perfectamente visibles al ojo humano, si bien se considera animales puros también a los que adquieren las aletas en su madurez ('Avoba Zara, 39, a).

De este modo, son impuros para los judíos todos los peces cartilaginosos y óseos en general, y más en concreto especies como la anguila, el congrio, la lamprea, la carpa y el tollo, así como el pulpo y todo el marisco y los crustáceos.

4t A.D.C., Inquisición, leg. 748/5-6, fol. 35 v². C. CarRete - C. Fralle, Fontes ludaeorum Regni Castellae, vol. IV, pág. 93. 
En algunos procesos inquisitoriales de fines del siglo $X V$ y de principios del XVI, algunos judeoconversos acusados de judaizar justificaban el rechazo de algunas especies de peces, o de animales en general, por motivos distintos de los puramente religiosos, lo que, sin duda, obedece a una estratagema en su defensa; así, afirmaban que no comían la anguila por la repugnancia que les producia su parecido con una culebra, el congrio porque les olia mal, o la liebre y el conejo porque eran "pelagudas" ${ }^{47}$. Pese a que todo invita a sospechar que estas argumentaciones obedecían a tácticas defensivas, es posible que en algunos casos la aversión hacia determinadas especies guardara también alguna relación con hábitos y costumbres alimentarias, es decir con factores de índole psico-social, y no sólo con motivaciones religiosas.

Por otra parte, son también impuros para los judíos todos los anfibios y los reptiles, así como la casi totalidad de los invertebrados, con la única excepción, como ya se indicaba anteriormente, de las especies con patas traseras más largas sobre las que saltan (langostas, saltamontes).

\subsection{La vigilancia del cumplimiento de las leyes kashrut.}

Las autoridades comunales judías se esforzaron en todo momento por garantizar una estricta observancia de las prescripciones alimentarias fijadas en la Torah y en el Talmud. Buen ejemplo de ello son las sanciones impuestas por los dirigentes de las aljamas a sus transgresores, y que en casos de especial gravedad podían ir acompañadas, incluso, de la pena de excomunión ${ }^{48}$. Tampoco son raras disposiciones dictadas por las autoridades comunales prohibiendo el ejercicio del oficio de shoet a personas que habían incumplido los preceptos relativos a la shehitah, así como a quienes habian vendido a judíos, engañosamente, carne procedente de animales impuros. En 1310 el batlle general de Aragón, atendiendo a la denuncia formulada por varios judíos de Daroca, multaba al rabí de esta aljama porque "non baccava dreytament, segunt ley de judios, al cuytiello con que degollava ${ }^{49}$. En 1311 Bonafós Addit, judío vecino de Huesca, fue inhabilitado por la aljama oscense para ejercer su oficio de carnicero, debido a que había degollado un cordero que no era apto para el consumo y lo vendía como si fue-

47 M.A. Motis Dolader, "Régimen alimentario de las comunidades judias y conversas en la Corona de Aragón en la Edad Media", pág. 241.

${ }^{48}$ La excomunión o anatema - en hebreo hérem - era pronunciada por el tribunal rabínico como castigo por una falta grave cometida contra individuos o contra la comunidad hebrea en su conjunto, o por la transgresión de un mandato religioso especialmente importante. Suponía el apartamiento radical de la comunidad por un periodo de tiempo indefinido.

49 Fritz BaER, Die Juden im Christlichen Spanien. //1. Aragonem und Navarra. Berlin, 1929, pág. 194 (citado por J. RIERA I SANS, "La conflictivitat de l'alimentació dels jueus medievals (segles XII-XV)", pág. 298). 
ra kasher ${ }^{50}$. En 1384 el batlle general de Valencia condenaba a Salomón Dasso a multa de 22 sueldos «per dal com furtà un gat e lo portà a la carnisseria per haver carn cassera $\$ 51$.

Todo hace pensar que, en general, el cumplimiento de la normativa dietética debió ser habitual entre los judíos de época medieval, fuera por propio convencimiento, por la estrecha vigilancia a que eran sometidos por las autoridades comunales, o por la repugnancia que les produciría el consumo de determinados alimentos, como el cerdo o la anguila.

No obstante, el rigor y la exactitud en la observancia de las leyes kashrut variaba mucho de unas a otras familias, de forma que la documentación bajomedieval ofrece noticias relativas a judíos que recurrían a judeoconversos conocidos suyos para que les encendieran el fuego el sábado para calentar el hamin, lo que de ningún modo era aceptable para un observante fiel de la Ley judía, quien no debe beneficiarse de la transgresión de las prescripciones relativas al shabat por parte de un no judio. Sin embargo, la constante reiteración de disposiciones dictadas por sínodos y concilios provinciales de época bajomedieval contra los cristianos que los sábados encendían el fuego y preparaban la comida a judíos, castigándoles con pena de excomunión, es una señal evidente de que se trataba de una práctica frecuente.

En la actualidad, pese a que numerosos judíos reformistas no consideran ya las leyes kashrut como algo de importancia fundamental en la práctica religiosa, los judíos ortodoxos continúan observándolas de forma estricta, pues consideran que no sólo son expresión de la voluntad divina, sino que también contribuyen a la santificación de la vida cotidiana.

No cabe ninguna duda de que estas peculiaridades en los hábitos alimentarios contribuyeron al progresivo rechazo social hacia los judíos. En particular porque sus contemporáneos cristianos no aceptaban la calificación de «impura» para ninguna especie animal ya que, como argumentaban los autores de algunos tratados doctrinales de época bajomedieval, el Nuevo Testamento considera buenas todas las especies creadas por Dios por lo que, en teoría, todas podrían ser consumidas; para el cristianismo, las prescripciones alimentarias bíblicas quedaron abolidas con la venida de Cristo ${ }^{52}$. Además, no debe perderse de vista que las diferencias en los hábitos alimentarios contribuyen siempre a dificultar la convivencia entre grupos sociales diferentes.

st Archivo de la Corona de Aragón (en adelante, A.C.A.), Canc. Reg. 208, fol. $14 \mathrm{r}^{2}$. Huesca 17.VI.1311. Jean REGGE, History of the Jews in Aragon. Regesta and Documents, 1213-1327. Jerusalem. The Hebrew University, 1978, núm. 2385; J. Riera, "La conflictivitat...", pág. 298.

${ }^{51} J$ J. RIERA I SANS, "La conflictivitat de l'alimentació dels jueus medievals (segles XII-XV)", pág. 298.

52 Josep HERNANDO, “Els moralistes i l'alimentació à la baixa Edat Mitjana”, en Alimentació i societat à la Catalunya medieval, págs. 271-293 (en concreto, págs. 274-275) 


\section{LA CARNE Y EL PESCADO EN LA ALIMENTACIÓN COTIDIA- NA DE LOS JUDÍOS HISPANOS.}

El menú cotidiano de los judíos en época medieval no difería sustancialmente del de sus contemporáneos cristianos, excepto en el rechazo por parte de los hebreos de determinadas materias primas de origen animal y en algunos modos específicos de preparación de los alimentos.

Pese a que el menú cotidiano variaba en función de la condición social y de la localización geográfica, en el mundo mediterráneo y en época bajomedieval se componía, básicamente, de cereales, legumbres, frutas y verduras, ovolácteos, carne, pescado, aceite y vino. De este modo, y aunque muy lejos de la dietética señalada como ideal en nuestro tiempo actual, no cabe duda de que existía un cierto equilibrio entre los hidratos de carbono o azúcares, los lípidos o grasas y las proteínas. El posible déficit calórico de la dieta se compensaba con algunos productos como el vino o la cerveza.

Señal evidente del interés por las cuestiones dietéticas entre los judíos de época medieval es el pasaje que a este tema dedica Moseh ben Maimón, Maimónides, en su tratado Sobre la unidad de Dios:

"Antes de la comida hacer media hora de ejercicios físicos, asearse y sentarse a la mesa a horas regulares, pues el cuerpo debe someterse a la disciplina de la voluntad. No comer sino cuando se tiene hambre y no llegar hasta el hartazgo; no beber sino cuando se tiene sed y no hacerlo durante la comida. Frutos emolientes precederán las comidas y frutos astringentes se tomarán con los postres. Las carnes deben ser ligeras y han de servirse con orden: las aves antes que otras carnes, los huevos antes que las aves. El pato, los pichones engordados y, en general, toda comida pesada y con grasas ha de ser descartada. El queso blanco fresco se servirá antes de la comida; nunca se comerán quesos secos y fermentados. No deben comerse criadillas de tierra y setas, pues producen enfermedades. Hay que evitar alimentos e ingredientes que miran más al placer que al provecho. No deben tomarse cosas heladas en verano y siempre pocas legumbres secas. Para los viejos un poco de vino y miel, sobre todo en invierno, son recomendables. La condición esencial para encontrarse bien es mantener regularmente el intestino vacio" 53 .

\subsection{La carne en la alimentación cotidiana de los judíos en época medieval. Diferentes formas de preparación de la carne.}

Al igual que para sus contemporáneos cristianos y musulmanes, la carne no era abundante en la dieta de los judíos más humildes, pero constituía el plato fuerte de toda comida, a mediodía y por la noche, para aquellas fami-

53. David Romano, La ciencia hispanojudia. Madrid. Mapfre, 1992, pág. 197. 
lias cuyas posibilidades económicas se lo permitía. La carne consumida era, principalmente, de carnero, de oveja o de cordero, de cabra o de cabrito y, en menor medida, de buey o de vaca. El ganado ovino y caprino era sacrificado, normalmente, dentro de sus dos primeros años de vida, en tanto que los bueyes y las vacas ya a edad adulta, tras haber sido empleados durante un buen número de años para tirar del carro o del arado.

Más frecuente era el consumo de la carne de aves permitidas por la religión judía, principalmente gallinas, capones, patos, ocas, ansarones, pichones y perdices, que resultaban bastante más asequibles para las familias con menores recursos económicos.

En general, cabe suponer que el consumo de carne en época medieval era sensiblemente mayor entre los judíos que entre los cristianos, teniendo en cuenta el elevado número de días al año en los que los cristianos tenían prohibido el consumo de productos cárnicos, que cabe cifrar entre los ciento cuarenta y los ciento cincuenta días.

\subsubsection{Guisos y cazuelas. El hamín o potaje del shabat.}

La carne se consumía en ocasiones sola, asada o guisada con aceite y especias, o, más normalmente, cocida como integrante principal de un potaje. En este sentido, no cabe ninguna duda de que los potajes ocupaban un lugar muy importante en la alimentación judía medieval. Entre ellos sobresale el hamín (en hebreo, "caliente»), que era conocido popularmente entre los judios hispanos como adafina, y entre los ashkenazíes como cholent, textualmente "caliente-lento", lo que define el único secreto de su preparación, que no es otro que la cocción a fuego lento, durante muchas horas.

Debido a que los judíos no pueden cocinar ni encender el fuego durante la fiesta del shabaft, el hamín debe ser preparado el viernes por la tarde, antes de la puesta del sol. Aunque la documentación conservada desde época medieval hasta la actualidad pone de manifiesto la existencia de una enorme variedad de recetas para la preparación del hamín, en la Edad Media se componía, básicamente, de carne --de bóvido, de ovino o de avelegumbres diversas — principalmente garbanzos o alubias-, verduras de temporada - berza, col, nabos, puerros, acelgas, espinacas-, huevos duros o haminados - cocidos con cáscara-, y especias - azafrán, pimienta-, además de aceite, cebolla y ajo. A causa del prolongado tiempo de cocción, el guiso queda bastante seco, de forma que casi parece frito en sartén, por lo que no es raro añadirle alguna salsa. Utilizando estos ingredientes básicos, el hamin era muy variado en función de la estación climática, de la producción agrícola y ganadera de la comarca y de las posibilidades de

${ }^{54}$ Las prescripciones relativas al descanso del sábado impuesto en la Torah (Éxodo, $X X, 8-11$ y XXXI, 12 18; Deuteronomio, V, 12-15) se encuentran en el tratado Shabat de la Mishnah, de la Tosefta y del Talmud. 
aprovisionamiento en los mercados locales o comarcales. A raiz del descubrimiento de América, la patata se convirtió en otro de los ingredientes fundamentales del hamín pero, lógicamente, en época medieval no se conocía. La elaboración de este guiso no es complicada, ni requiere de grandes dotes culinarias; los diversos ingredientes se introducen juntos en una olla y se guisan simultáneamente hasta que se completa la cocción.

Una vez preparado el guiso, la olla se colocaba al fuego en un anafe o pequeño horno y se cubría con brasas y rescoldos, a fin de que cuando el fuego se apagara conservara algo de calor hasta el sábado a mediodía. Pese a todo, el hamín se comía templado o, incluso, frío, por lo que uno de los argumentos que se esgrimían en los procesos inquisitoriales para demostrar que un judeoconverso judaizaba era afirmar que los sábados «comía frío", como "fiambre».

Los procesos inquisitoriales de fines del siglo XV y de los primeros decenios del XVI contienen numerosas referencias al proceso de elaboración del hamin, en las que queda de manifiesto el largo tiempo de cocción. Es lo que cabe deducir de la declaración que en el año 1501 hizo ante el tribunal de la Inquisición Bartolomé Rodríguez, judeoconverso vecino de Sigüenza, quien confesó

"... que algunos jueves ha conprado menudos de carnero o de vaca y pezuñas, para comer en sábados, y los dexava coziendo el viernes en las noches quando se quería yr a dormir, y cozian fasta la ora de comer, y echava en ello garvanços; y que no lo fazía por çeremonia 255 .

También María de Xódar, vecina de Almazán, declaró ante el tribunal de la Inquisición que algunos viernes por la tarde su ama Leonor, mujer de Pedro Méndez el tendero, cristianos nuevos vecinos de dicha localidad soriana, le ordenaba

«... que tomase las tripas de carnero o vaca e manos e pies de carnero e uñas de vaca, que avían tomado el jueves antes, las cozinase en una olla para otro día sábado; y que este testigo lo fazía asy', por mandado de... su ama; y que echava nabos al tienpo que los avia, y que asy' se estava la olla al fuego coziendo fasta otro día, sábado, que la comian a ora de comer; e que de aquella olla comian... sus amos y este testigo" ${ }^{56}$.

Pero además del hamín, la documentación inquisitorial ofrece abundantes e interesantes noticias acerca de otras diversas formas que judíos y ju-

${ }^{55}$ A.D.C., Inquisición, leg. $749 / 14$, fol. $9 r^{\circ}$. C. CARRETE - C. Fralle, Fontes ludaeorum Regni Castellae, vol. IV. pág. 104.

5* A.D.C., Inquisición, leg. 749/15, fol. 17. C. CARRETE - C. Fralle, Fontes ludaeorum Regni Castellae, vo. IV, pág. 79 . 
deoconversos tenían de preparar la carne; en ocasiones, la minuciosidad en la descripción convierte a estas referencias documentales en auténticos recetarios.

Además de a los guisos o cazuelas, a base de carne, legumbres y verduras diversas, huevos, queso y especias, hay abundantes referencias a "pasteles" o "pastelejos" de carne, que se elaboraban a base de carne de cordero, cabrito, palominos o pollo envuelta en masa cocida al horno.

\subsubsection{Cecinas.}

Era también habitual cecinar la carne de vaca, de oveja o de cabra, salándola y dejándola secar al aire, al sol o al humo, lo que permitía conservarla durante un periodo más prolongado de tiempo. En cumplimiento de las prescripciones dietéticas judías, antes de cecinarla, lavaban la carne de forma minuciosa para que quedara totalmente limpia de sangre y la purgaban quitándole todos los sebos y grasas. De este modo Gonzalo, platero judeoconverso de Soria, fue acusado de que en su casa

«... fazían çeçina de vaca, e quera en tienpo que suelen fazer çeçinas en la dicha çibdad, e que para las ansí fazer estavan purgando la... carne, como los judios fazen, su muger e fijas de... Gonçalo, platero" 57 .

Además de todos los sebos, antes de cecinar la carne de las patas traseras de los animales les retiraban también la landrecilla. Así se deduce de la declaración que hizo ante el tribunal de la Inquisición Juan de la Parra, vecino de Coruña del Conde, quien afirma que en algunas ocasiones habia visto en casa de Pedro Núñez cómo su mujer Constanza Núñez y su criado Alonso, cristianos nuevos vecinos de dicha localidad burgalesa,

«... abrian por medio las piernas de cabrones e cabras, que echavan en sal, e les sacavan de enmedio la landrezylla e sebo e lo echavan; e que sabe que hera la landrezylla porque lo a visto sacar/... quando heran judios abrian las piernas para salgar (= salar) e çeçinallo (= cecinarlo) ${ }^{58}$.

\subsubsection{Cabaheas.}

Son también muy frecuentes las referencias documentales a la preparación por parte de los judeoconversos de cabaheas, que comían normalmente los sábados a mediodía. Las cabaheas se preparaban a base de la cabeza de una res - buey, carnero o cabrito-, que se cocía junto con las

${ }^{57}$ A.G.S., Patronato Real, Inquisición, leg. 28/73, fol. $981 v^{2}$. C. CARRETE, Fontes ludaeorum Regni Castellae, vol. II, pág. 50.

58 A.G.S., Patronato Real, Inquisición, leg. 28/73, fol. 1066 r ${ }^{\circ}$. C. CARRETE, Fontes ludaeorum Regni Castellae, vol. II, pág. 91. 
entrañas o «livianos" - bazo, hígado, pulmones, corazón, bofes-; tras la cocción, la carne se picaba y se condimentaba con sal, ajo, especias - culantro seco, pimienta- y huevos cocidos, y se introducía a modo de longaniza en tripa de animal, atándola con un hilo. Una vez embutida, la carne se dejaba curar durante algún tiempo; para comerlas, se freían o se asaban. Las cabaheas eran, así pues, algo parecido al bojillo de Tierra de Campos, Zamora y León, y al skamba de los sefardies ${ }^{59}$.

Entre las abundantes referencias documentales a la elaboración de cabaheas, es muy gráfica la declaración que el día 3 de junio de 1505 hizo ante el tribunal de la Inquisición Juan de Ribacho, vecino de la localidad palentina de Frechilla, quien afirmó

“... que vido en el dicho tienpo, viniendo este testigo de casa de su padre, que avía ydo a mudar sus vestidos, vido cómo en casa de... Antón del Valle cristiano nuevo vecino de Almazán- tenían colgadas unas como longanizas, e preguntó de qué heran fechas, y le dixeron... sus amos que de livianos de buey; e que se las vido comer, e este testigo no quiso comer dellas por miedo que heran cabaheas, como quando heran judios; e las asavan en el rescoldo 60

No menos interesante es la declaración de María, hija de Juan Sancho, vecina de Aguaviva ${ }^{61}$, quien el día 17 de junio de 1505 testificó ante el tribunal de la Inquisición que hacía dos años que vivía con Cristóbal de León y con su mujer Angelina, cristianos nuevos vecinos de Almazán,

"... e que en este tienpo ha visto cómo en casa de... sus amos han matado en cada año un buey e quatro cabrones, e... Angelina mandava a este testigo que las cabeças del buey e cabrones las echase a cozer el domingo en la noche, e después de cozidas las picava... su ama e las echava en los alvillos (= tripas) de los cabrones, e las ponía a sahumar (= ahumar), e después comía dellas... su ama los dias de carne, e no comía otra persona de casa dellos" 62 .

Asimismo Teresa, mujer de Alonso Sancho, vecina de la localidad de Varca, en el arciprestazgo de Almazán, declaró el 4 de junio de 1505 ante el tribunal de la Inquisición que

C. Carrete - C. Fraile, Fontes ludaeorum Regni Castellae, vol. IV, pág. 24.

A.D.C., Inquisición, leg. 748/5-6, fol. 31 vo. C. CarRete - C. Fraile, Fontes ludaeorum Regni Castellae, vol. IV, págs. 111-112.

Se trata de Aguaviva de la Vega, pequeña localidad situada al sur de Almazán.

${ }^{\prime 2}$ A.D.C., Inquisición, leg. 749/15, fol. $22 \mathrm{r}^{\circ}-\mathrm{v}^{2}$. C. CaRRETE - C. Fralle, Fontes ludaeorum Regni Castellae, vol. IV, pág. 32. 
«... vio por el tienpo del ynvierno cómo... sus amos mandavan traher, y los traýa... Pero Vélez - difunto, portazguero, cristiano nuevo- unos alvillos (= tripas) de la carneçería, e livianos, e carne, e dávanlos a... Leonor, su fija, la qual los fazía como torteruelos, todos atados en una cuerda, de manera que los judios lo solian fazer, segund que ha oydo este testigo, y lo comian en los dias de carne ${ }^{63}$.

\subsubsection{Albóndigas o albondaquillos.}

Era también muy frecuente entre judíos y judeoconversos el consumo de la carne en forma de albóndigas o albondaquillos. Consistían, simplemente, en unas bolas de carne picada, condimentada con especias diversas y, en ocasiones, mezclada con alguna verdura, principalmente con puerros. Se hacían en sartén con un sofrito de aceite de oliva, y se acompañaban en la mesa con una salsa, con frecuencia de limón o de tomate ${ }^{64}$. En ocasiones los albondaquillos se embuchaban en tripa de carnero que, atada con hilo, se cocía en caldo. Una vecina de Almazán, Ilamada Ana, declaró ante el tribunal de la Inquisición que durante el tiempo en que convivió con Ruy Díaz Laínez y con su mujer Beatriz, cristianos nuevos vecinos de Almazán, vio

“... cómo algunas vezes picavan una poca de carne cruda e la echavan en un mortero, e allí echavan espeçias e algunos huevos, e majavan aquello, e después de majado fazían unos como bodoques redondos e los freyan en una sartén con azeyte o en una olla, e los llamavan albondaquexos, e de aquéllos comian... sus amos" 65 .

\subsubsection{Empanadas y tortas de carne.}

Tampoco era inusual la preparación de empanadas y tortas de carne, que se elaboraban con cabezas de carnero cocidas y con carne picada frita en aceite. Las empanadas eran muy propias del shabat y, como dice frecuentemente la documentación, judíos y judeoconversos «las comian con mucho plazer y fiesta" ${ }^{66}$.

" A.D.C., Inquisición, leg. 748/5-6, fol. $33 r^{\circ}-v^{2}$. C. CarRete - C. Fralle, Fontes ludaeorum Regni Castellae, vol. IV, pág. 117

${ }^{54}$ M.A. Moris DOLADER, cRégimen alimentario de las comunidades judias y conversas en la Corona de Aragón en la Edad Media", págs. 343-344.

Es A.D.C., Inquisición, leg. 749/15, fol. 20 r $^{\circ}-v^{\circ}$. C. Caraete - C. Fralle, Fontes ludaeorum Regni Castellae, vol. IV, págs. 43-44.

b. A.D.C., Inquisición, leg. $749 / 15$, fol. 1 vo. C. Caraete - C. Fralle, Fontes ludaeorum Regni Castellae, vol. IV, pág. 122. 


\subsection{El pescado en la alimentación cotiana de los judíos en época medieval.}

El pescado constituía otro de los elementos básicos de la alimentación de los judíos en la España medieval, lo que no resulta extraño si tenemos en cuenta que el pescado fresco era ya muy apreciado por los judios en los tiempos bíblicos. Por este motivo, algunas aljamas judías se esforzaron por garantizar a sus individuos el aprovisionamiento de pescado, llegando a obtener en casos extraordinarios, incluso, derechos de pesqueria en aguas reales.

El pescado es además, tradicionalmente, un ingrediente fundamental en la cena del viernes, con la que se inicia en la familia judía la celebración del shabat. La presencia del pescado en la cena del viernes es una tradición judía muy antigua, lo que guarda relación, muy probablemente, con la esperanza mesiánica. Así, si el shabat supone en el judaísmo una preparación para la venida del Mesías esperado, el pez tuvo siempre entre los judíos una consideración muy especial entre todas las especies animales, asociándosele con frecuencia con la venida del Mesías ${ }^{67}$. Algunos escritos rabínicos de exégesis acerca del libro del Génesis sostienen que en tiempos del patriarca Noé los animales, como los hombres, eran también pecadores; todas las especies eran pecadoras excepto las criaturas marinas, motivo éste por el que fueron las únicas que sobrevivieron al Diluvio Universal. Asimismo, en algunas concepciones milenaristas judias de época medieval existía la creencia de que antes de que se produjera la venida del profeta Elias anunciando la inminente llegada del Mesías y el consiguiente fin del mundo, se produciría un violentísimo enfrentamiento entre dos criaturas míticas sobrenaturales: el Behemot, un monstruo marino que algunos identifican con un enorme hipopótamo ${ }^{68}$, y el Leviatán, una especie de dragón marino o fluvial, quizá un cocodrilo gigantes $\mathrm{c}^{69}$. Ambas criaturas morirían y quedarían despadazadas como consecuencia de su brutal enfrentamiento, sirviendo de alimento en el banquete de los justos que tendría lugar tras la llegada del profeta Elías.

\footnotetext{
Nc hay que olvidar que entre los primitivos cristianos el pez era uno de los simbolos identificativos utilizados en la clandestinidad romana, lo que guarda relación con la identificación de Cristo con el Mesias esperado.

BH Behemot es un término hebreo que significa "la bestia" por excelencia. Se trata de una fiera gigantesca y malvada, cuyo modelo es, muy probablemente, el hipopótamo, considerado en el antiguo Egipto como un animal sagrado aunque demoniaco. Es citado, junto al Leviatán en el libro de Job (40, 15-24), en el que se señala que únicamente Dios es capaz de someterle. La tradición dio el nombre de Behemot al demonio, del que quizá sea imagen (André-Marie Gerard y Aridrée Nordon-Gerard, Diccionario de la Biblia. Madrid. Anaya \& Mario Muchnik, 1995, pág. 166)

${ }^{64}$ Leviatán es un término hebreo, de procedencia incierta, con el que se hace referencia en diversos pasajes bíblicos (Salmos, 74, 14, y 104, 26; Isaias, 27, 1; Job, 40 y 41) a un monstruo sobrenatural que personifica el caos y el mal, al igual que la Serpiente, el Dragón, Behemot y Rajab. Es originario, muy posiblemente, de la mitología cananea, más concretamente de la fenicia, desde la que se introdujo en el folclore hebreo (A.-M. Gerard y A. Nordon-Geraro, Diccionario de la Biblia, pág. 836).
} 
Entre los judíos sefardíes era también habitual un plato de pescado en la comida del shabat. Con el fin de cumplir con la prescripción que prohibe cocinar y encender el fuego durante la fiesta del shabat, el pescado que iban a consumir en este día lo freían el viernes por la tarde y lo marinaban ${ }^{70}$, comiéndolo al día siguiente frío, normalmente como entrante.

Las especies consumidas - siempre, preceptivamente, con aletas y escamas- variaban de unos a otros lugares, en función de la proximidad del mar o de un río. En la documentación inquisitorial se encuentran referencias a judeoconversos que consumían barbos, truchas, sardinas, merluza, atún y besugo, entre otras variadades de peces. Como en muchas localidades del interior no era fácil disponer de pescado fresco, era muy frecuente el consumo de pecado seco, ahumado o en salazón, lo que garantizaba su conservación durante un período más prolongado de tiempo.

Aunque la documentación no ha conservado demasiadas noticias acerca de las distintas formas de preparación del pescado, todo hace pensar que predominaba su consumo frito, asado o guisado.

Como ya se ha indicado anteriormente, no era infrecuente que judios y judeoconversos comieran el día del shabat un plato de pescado. La documentación inquisitorial de fines del siglo $X V$ y de los primeros decenios del $X V I$ recoge abundantes referencias a cazuelas de pescado que, como las de carne, comerían frías o, a lo sumo, templadas - fiambre, según la documentación de la época-, por la prohibición de encender el fuego en esa festividad. Estas cazuelas de pescado se elaboraban a base de pescado (sardinas, atún), huevos, legumbres, verduras de temporada (zanahorias, berenjenas, habas), ajo, cebolla y especias. Así, en el proceso inquisitorial promovido contra Leonor Álvarez, mujer de Fernando Álvarez (1512-1514), cristianos nuevos vecinos de Ciudad Real, un testigo declaró que un día antes del mes de agosto de 1511 había visto a la acusada

“... e a otras çiertas personas, un día de sábado merendar de una caçuela de pescado e çanahorias e huevos e espeçias, fiambres, que paresçió a este testigo que hera guisada de un día antes, porque estaba fría e seca la dicha caçuela» ${ }^{71}$.

Otras judeoconversas vecinas también de Ciudad Real, Beatriz, mujer de Juan de la Sierra, su madre Leonor, e Isabel González, mujer de Rodrigo de Villarrubia, fueron acusadas de comer los sábados lo que tenían guisado del viernes, porque, como se dice en la acusación presentada por el promotor fiscal en el proceso inquisitorial promovido contra ellas, solían

"El adobo para marinar se preparaba, normalmente, a base del propio aceite de freir el pescado, así como con laurel y romero, vinagre, sal y pimienta.

A.H.N., Inquisición de Toledo, leg. 133, n. ${ }^{9} 21$, fol. $18 \mathrm{r}^{\circ}$. H. BeInaRT, Records, vol. It, pág. 346. 
“... guisar los dichos viernes para los sábados caçuelas de pescado e sardinas, e las vezes con verengenas e con çevollas y culantron y espeçias, e las comían en los dichos sábados syguientes" $72^{2}$.

En alguna ocasión se hace referencia en documentación inquisitorial a que ciertos judeoconversos comían los sábados una salpimentada, que dejaban preparada el viernes por la tarde. En mi opinión, se trata de una cazuela de pescado, y el nombre que se le da quizá haga referencia a su condimentación a base de sal y pimienta. El 24 de mayo de 1503 testificó Ana Núñez, mujer de Antón de Morales, vecino de Ciudad Real, en el proceso inquisitorial promovido contra su vecino Luis Fernández (1503-1504), sastre, cristiano nuevo vecino de Ciudad Real, y declaró

«... que del dicho tienpo acá (cuatro años) le ha visto bien quatro o çinco días ayunar e no comer en todo el día fasta la noche, e la una vez destos días que ayunaron, este testigo miró en ello e lo tiene bien notado, fue jueves antes de Santa María de setienbre venidero avrá dos años, e aquel día non trabaxó, antes holgó, e comieron una sal pimentada que ellos dezían como caçuela e unas sardinas, la sal pimentada del día antes. E a su ver e conosçer deste testigo, non le tiene por buen christiano, antes le tiene por más judío que christiano " ${ }^{73}$.

No era tampoco infrecuente consumir el pescado los sábados en forma de empanadas, que se dejaban preparadas el viernes por la tarde. El 22 de diciembre de 1488 testificó ante el tribunal de la inquisición la judía Jamila, mujer de don Symón abén Fara, tratante ya difunto, vecina de la localidad segoviana de Fuentidueña, y declaró

«... que byviendo en Aranda, vyo este testigo que Diego Garçía Costello e su muger, vezinos de dicho lugar, que hera sastre, después se hizo çurujano, hazía empanadas de pescado el vyernes para el sábado; e los vía folgar los sábados; e llevava carne de la judería» ${ }^{74}$.

Otras recetas sefardíes, conocidas a través de las comunidades establecidas en el Oriente Próximo tras la salida de los reinos hispanos en 1492, nos hablan de platos de pescado asado, elaborados a base de pescados de sabor fuerte como atún o caballa, tomate, verduras amargas (endivias), ciruelas y hierbas aromáticas mediterráneas (eneldo, hinojo, orégano, tomillo).

Finalmente, la documentación hace alusión asimismo a albóndigas de pescado, consistentes en unas bolas hechas a base de pescado triturado, que se escalfaban en caldo vegetal. Con frecuencia, las albóndigas de pes-

A.H.N., Inquisición de Toledo, leg. 153, n. 14 , fol. $4 v^{0}$. H. BEINART, Records, vol. II, pág. 163.

A.H.N., Inquisición de Toledo, leg. 147, n. ${ }^{2}$, fol. $2 \mathrm{v}^{2}$. H.BEINART, Records, vol. II, pág. 135.

${ }^{4}$ A.G.S., Patronato Real, Inquisición, leg. 28/73, fol. $1113 r^{2}$. C. CARRETE, Fontes Iudaeorum Regni Castellae, vol. II, pág. 173. 
cado se acompañaban con agristada, una salsa típicamente sefardí que se elaboraba con caldo vegetal, huevo batido, harina y jugo de limón.

Con pescado se elaboraban también unas tortas o pasteles (entre las comunidades sefardies del Próximo Oriente son conocidas en turco con el nombre de keftedes) que, una vez rebozadas en pan rallado, se freían en aceite. Estas tortas eran muy frecuentes en la cena del viernes como aperitivo.

\subsection{La condimentación de los platos de carne y pescado.}

Los platos de carne y pescado eran condimentados por judíos y judeoconversos, habitualmente, con ajo y cebolla, así como con especias diversas (principalmente, pimienta, azafrán, cilantro, mostaza y clavo) y plantas aromáticas mediterráneas (tomillo, romero, orégano, eneldo, salvia, ajedrea, hinojo, albahaca, comino y anis).

Con estos diversos ingredientes, junto con aceite y sal, vinagre, vino, agraz, jugo de limón o de naranja, y manzana verde, elaboraban diversas salsas que resultaban un complemento fundamental para carnes y pescados, ayudando a disimular los malos olores, y aún los malos sabores, de un pescado o de una carne no demasiado fresco, o, simplemente, contribuyendo a mejorar el gusto de potajes y guisos.

Como ya se ha indicado anteriormente, el pescado hervido y frito, así como las albóndigas y las tortas de pescado, se acompañaban con frecuencia con la salsa conocida como agristada. También eran frecuentes entre los sefardies para acompañar el pescado frito una salsa de nueces que recuerda algo al haroset ${ }^{75}$ del séder de Pésah, una salsa agridulce a base de tomate $y$ vinagre, $y$ una salsa vinagreta cuyos ingredientes principales eran el limón y el ajo.

De lo que se acaba de indicar se deduce fácilmente que, como la cocina europea en general, la cocina judía se caracterizaba a fines de la Edad Media por una marcada indiferenciación entre platos salados y azucarados, por el uso abundante de especias y de hierbas aromáticas, y por una indiscutible predilección por los sabores ácidos, lo que era el resultado de las diversas salsas con las que acompañaban potajes, carnes y pescados.

Pasta elaborada a base de frutas diversas machacadas en un mortero, mezcladas con canela u otras especias, harina sin levadura, miel y vino, y que constituye uno de los elementos fundamentales del séder o cena ritual de la Pascua (en hebreo, Pésah). Aun cuando nada seguro cabe afirmar acerca del ori. gen etimológico de la palabra haroset, tradicionalmente se ha considerado derivada de héres (= barro), de forma que el haroset sería un símbolo del barro con el que los israelitas fabricaban adobes durante la esclavitud de Egipto. 


\section{LA ORGANIZACIÓN PÚBLICA DE LA ALIMENTACIÓN EN LAS COMUNIDADES HISPANOHEBREAS EN EPOCA ME- DIEVAL.}

Al abordar el estudio de cualquier aspecto relativo a la alimentación de los judios en la España medieval hay que prestar atención, necesariamente, a la compleja maquinaria que las aljamas hebreas habian de poner en marcha con el fin de garantizar un adecuado aprovisionamiento de víveres para sus integrantes, así como a la variada infraestructura de que disponían a este fin. Por lo tanto, haremos seguidamente una breve referencia a estas cuestiones en lo que se refiere al aprovisionamiento de carne y pescado a las juderías.

\subsection{El avituallamiento de carne y pescado a aljamas y juderías.}

Pese a lo que con demasiada frecuencia se afirma, en mi opinión no debían ser pocos los judios que intervenian de forma directa en la producción de bienes de consumo, lo que contribuía en alguna medida a garantizar a las comunidades hebreas el abastecimiento de productos agrícolas, en particular el vino y los productos de huerta.

Asimismo era bastante frecuente que las aljamas judías mantuvieran un cierto número de cabezas de ganado, vacuno y lanar, con el fin de abastecer la carnicería judía. Para la alimentación de este ganado, las aljamas disponían de prados propios, y recibían licencias de las autoridades concejiles a fin de que pudieran llevar a pastar un determinado número de reses a las dehesas concejiles. De este modo, a mediados del siglo XV la aljama judía de Haro contaba con la autorización del concejo de esta localidad riojana para llevar a pastar a los prados del común del concejo hasta cincuenta cabezas de ganado lanar y diez cabezas de ganado vacuno ${ }^{76}$, y la aljama de Huesca podía hacer lo propio con hasta cien cabezas de ganado $\operatorname{lanar}^{77}$.

Así, por tanto, y pese a que el uso por parte de los ganados de las aljamas hebreas de los pastos del común del concejo constituyó una fuente inagotable de conflictos entre aljamas y concejos a lo largo de toda la Baja Edad Media, en general se trató siempre de establecer un marco de coexistencia y de fijar unas normas de compromiso que garantizaran el abastecimiento alimentario de las comunidades judias. Las fórmulas acordadas pasaban, normalmente, por otorgar a las aljamas autonomía para resolver estas cuestiones, a cambio del pago de ciertos gravámenes sobre el consumo de determinados alimentos. De este modo, las aljamas estaban autori-

Enrique Cantera Montenegro, Las juderias de la diócesis de Calahorra en la Baja Edad Media. Logroño. Instituto de Estudios Riojanos, 1986, pág. 380.

Ricardo del ARCO, "La judería de Huesca. Noticias y documentos inéditos", en Boletin de la Real Academia de la Historia, LXV| (1915), págs. 341-342 
zadas a controlar la distribución de los productos de primera necesidad, como la carne y el vino, garantizando su condición de kasher, así como a fijar sus precios. Además de con las sisas reales o concejiles, que afectaban al conjunto de la población, los judios veían también gravado el precio de la carne -como el del vino- con unas tributos específicos fijados por las propias aljamas, cuya finalidad no era otra que recaudar ciertas cantidades que permitieran sufragar diversos gastos de carácter comunitario, como el salario del maestro de los niños o los ocasionados por el mantenimiento del hospital de la judería.

Las comunidades judias, como las mudéjares, disponian de canales propios para la distribución y venta de los productos alimentarios; eran, principalmente, carnicerías, pescaderías, tabernas y la denominada «tienda de la aljama", a las que se hará referencia más adelante. No obstante, y aunque habitualmente los judios se aprovisionaban en los establecimientos comerciales propios de la judería, con frecuencia habían de acudir también al mercado de la localidad. Por este motivo, la mayor parte de los fueros y ordenanzas concejiles de los distintos reinos hispanos contienen disposiciones que regulan la presencia de los judíos en el mercado ${ }^{78}$.

En general, los mercaderes judíos eran considerados en un plano de marcada igualdad con respecto a los cristianos y musulmanes, prohibiéndose en diversos códigos municipales que se les prendara en sus productos mercantiles, excepto en el caso de que tuvieran deudas o de que hubieran entrado como fiadores.

Sin embargo, y como una manifestación más de las restricciones a que se veían sometidos los judíos en los más diversos ámbitos de la Europa occidental y central desde los siglos de la Plena Edad Media, los fueros y las ordenanzas concejiles recogían con frecuencia en su articulado algunas limitaciones a la libre actuación de los judíos en el mercado.

Desde muy pronto, las autoridades concejiles y religiosas cristianas manifestaron una preocupación creciente por el hecho de que los judios tuvieran contacto directo con los alimentos en el mercado, por lo que en diversos textos legales - principalmente concejiles - se les prohibe manipular los productos alimentarios. De este modo, con frecuencia se les obliga a utilizar una vara "de dos palmos o más" para señalar los alimentos; así, en el año 1350 los consellers de Lérida disponian que ningún judío o judía

${ }_{76}$ Un análisis detenido acerca del tratamiento de la cuestión judía en los fueros y ordenanzas concejiles puede encontrarse en los trabajos de Pilar León Tello, "Disposiciones sobre judios en los fueros de Castilla y León", en Sefarad, XLVI (1986), págs. 279-293 (también publicado en Medievalia, VIII (1989), págs. 223-252), José M. ${ }^{a}$ MONSALVo ANTON, Teoría y evolución de un conflicto social. El antisemitismo en la Corona de Castilla en la Baja Edad Media. Madrid. Siglo XXI, 1985 (en concreto, págs. 137143), y Fernando SuÁREz BILBAo, El Fuero Judiego en la España Cristiana. Las fuentes jurídicas. Siglos V-XV. Madrid. Dykinson, S.L., 2000 (en concreto, págs. 55- 82 y 170-247). 
"... no gos mercadejar ab la mà nua ni en altra manera tochar ab la mà negun pa, fruyta ni altres coses que.s venen en la ciutat, sino ab una vergueta que porten en la mà» 79 .

Esta prohibición, idéntica a la que recaía también sobre las prostitutas, obedecía, por tanto, a razones de higiene moral y social, y no a motivos de profilaxis, y se sustentaba en el principio de la "intocabilidad" del judío, es decir en la consideración de que, debido a su perversión moral, el judío contamina todo lo que toca.

Por otra parte, y por motivos de índole principalmente socio-religiosa, se establecieron también algunas limitaciones para los judíos en la adquisición de determinados productos alimentarios, en particular la carne y el pescado. Los ejemplos se suceden en fueros y ordenanzas concejiles de muy diversas localidades hispanas.

Los fueros de Coria y de Cáceres, otorgados por el rey Alfonso IX de León en 1208-1210 y en 1229, respectivamente, gravan el pescado que los judíos compran los viernes en el mercado con un maravedí, que habrían de satisfacer a los alcaldes. Asimismo, si un cristiano comprara pescado para un judío en viernes habria de satisfacer también a los alcaldes dicho maravedí adicional ${ }^{80}$.

En 1299 se hizo pública en Perpiñán una ordenanza municipal en la que se prohibía a los judios tocar las vituallas expuestas en el mercado antes de adquirirlas, así como comprar antes de tercia, con el fin de impedir que se hicieran con los mejores productos, en particular con el pescado ${ }^{81}$.

El fuero de Sepúlveda, en la confirmación que hizo el rey Fernando IV en 1309, prohibe a los judíos comprar carne en el mercado, excepto de cabra o cabrón, los días de Pascua Mayor (Domingo de Resurrección), de Navidad y de Pentecostés, así como tres días antes y tres días después de estas fiestas; quien contraviniere esta prohibición perdería la compra ${ }^{82}$.

En las ordenanzas dadas a mediados del siglo XIV a la villa de Peñafiel por don Juan, hijo del infante don Juan Manuel, se prohibe a los judios comprar pescado antes de mediodia ${ }^{83}$.

\footnotetext{
"J. RIERA I SANS, "La conflictivitat de l'alimentació dels jueus medievals (segles XII-XV)", págs. 300301.

F. SuAREz, El Fuero Judiego en la España Cristiana, págs. 181 y 189.

"J. RiERA I SANS, "La conflictivitat de l'alimentació dels jueus medievals (segles XII-XV)", pág. 300.

az F. SUÁREz, El Fuero Judiego en la España Cristiana, pág. 211.

${ }^{83}$ José Mà MONSALvo. Teoría y evolución de un conflicto social, pág. 141.
} 
Las ordenanzas de Toledo, de diversas épocas, prohiben a los pescadores vender pescado fresco en la judería los miércoles, los jueves y los viernes de Cuaresma, en las cuatro Témporas ${ }^{84}$ y en las vigilias de los santos. Asimismo se prohibe a los cristianos comprar carne para compartirla con judíos y mudéjares ${ }^{85}$.

Las ordenanzas de Córdoba de 1435 prohiben a los judíos comprar pescado fresco antes de mediodía los miércoles, los viernes y durante la Cuaresma, bajo pena de multa de 12 maravedies y de pérdida del producto comprado ${ }^{86}$.

Con el paso del tiempo las restricciones fueron haciéndose más severas, como es fácil comprobar en el caso concreto de la ciudad de Segovia. Así, en otoño de 1488 el concejo dispuso que, en adelante, los judíos no podrían comprar pescado los viernes, cuando con anterioridad sí podian hacerlo a partir de la hora de tercia. Asimismo les prohibe la compra de carne y de aves los jueves antes de mediodía, y la venta de sal, de besugos secos y de otros viveres en la plaza de la ciudad ${ }^{87}$.

Como ya se ha indicado con anterioridad, estas restricciones tienen en muchos casos un indudable trasfondo socio-religioso, en particular aquellas que afectan a la adquisición de pescado; su objetivo no era otro que garantizar a los cristianos la disponibilidad de este producto en los días de vigilia, en los que tenían prohibido el consumo de carne.

Pero, al margen de estas limitaciones, que afectan de forma exclusiva a la adquisición de determinados productos alimentarios en el mercado, da la impresión de que, en general, las aljamas judías recibieron garantías por parte de los concejos para el aprovisionamiento de víveres, en particular por lo que se refiere a la carne y al vino - dos productos cuya condición de kasher debia ser minuciosamente vigilada por las autoridades rabínicas-, lo que es un claro indicio de que existía el convencimiento de que la alimentación de los judíos comportaba una problemática socio-religiosa particular, que exigía un tratamiento especial. De este modo, las ordenanzas concejiles de diversas localidades autorizaban a las comunidades hebreas la importación de vino judiego o kasher, antes incluso de que se hubiera consumido el vino de producción propia, a cambio tan sólo del pago de

\footnotetext{
Sas Témporas fueron instituidas por el papa San Calixto I en el siglo III. Consisten en unos períodos de tres dias de duración (miércoles, viernes y sábado) del calendario litúrgico cristiano en los que se exigia ayuno y oración más intensa. Estos periodos vienen a coincidir con el comienzo de las distintas estaciones del año: las Témporas de primavera coincidian con la primera semana de Cuaresma; las Témporas de verano con la semana de Pentecostés; las Témporas de otoño con la $17^{a}$ semana después de Pentecostés; y las Témporas de invierno con la tercera semana de Adviento.

s. José Ma Monsalvo, Teoría y evolución de un conflicto social, págs. 142-143.

8* F. SUAREZ, El Fuero Judiego en la España Cristiana, pág. 247.

8. A.G.S., Registro General del Sello, fol. 200 , documento de noviembre de 1488, y fol. 255 , documento de enero de 1489. Luis SuAREz Fernandez, Documentos acerca de la expulsión de los judíos. Valladolid. Consejo Superior de Investigaciones Cientificas, 1964, pág. 41, nota 14.
} 
ciertos gravámenes. Del mismo modo, la documentación demuestra que, con frecuencia, los reyes facilitaban a las aljamas la disposición de mataderos propios o la posibilidad de disponer del matadero concejil para que el shoet degollara a los animales con arreglo al ritual de la shehitah; e, incluso, llegaron a autorizar la venta de carne judiega o kasher a quien deseara comprarla, independientemente de que fuera o no judío. Mayores fueron, por el contrario, las restricciones impuestas al respecto por las autoridades eclesiásticas y concejiles. Así, algunas bulas y cánones de sínodos y concilios provinciales, principalmente del siglo XV, castigaban con pena de excomunión a los cristianos que consumian alimentos propios de judíos, y de forma particular la carne desechada por ellos por considerarla terefah o trifá. En un sínodo que se celebró en Lérida, y que ha sido atribuido al obispo fray Ramón (1248-1254), se establecía la pena de excomunión para los carniceros que vendieran a cristianos carne rechazada por los judios ${ }^{88}$. En la órbita municipal son también muy antiguas disposiciones en las que se castiga la venta de carne judiega a cristianos; asi, en el fuero de Madrid, otorgado por el rey Alfonso VIII en torno al año 1202, se pena al carnicero que vendiera a cristianos carne de judíos trifá, u otra cualquiera carne judiega, con multa de doce maravedies, y si no la pagara con la horca ${ }^{89}$.

El problema que se planteaba en las comunidades hebreas para dar salida a la carne no apta para el consumo de los judíos al descubrir, tras el sacrificio de un animal, que presentaba una tara interna que lo convertía en impuro, o al quedar la carne ensangrentada por una práctica incorrecta de la shehitah, era de gran magnitud. Por este motivo, las autoridades de algunas aljamas buscaron soluciones ingeniosas que, en ocasiones, bordeaban la legalidad. Es éste el caso del acuerdo al que, a principios del siglo XIV, $\|$ egaron los judíos de E!che con el carnicero cristiano de esta localidad: el rabino - o shoet-sacrificaría todos los animales; los que fueran aptos para el consumo de los judíos pasaban a la carnicería judía, y los restantes a la carnicería cristiana. Este acuerdo debió tener vigencia durante algún tiempo pero, finalmente, fue anulado por el rey Jaime II de Aragón en 1312, por considerarlo indecoroso para los cristianos, que comerían la carne manipulada, palpada y rechazada por los judios ${ }^{90}$.

Pero acuerdos similares a éste no debieron ser infrecuentes entre aljamas judías y carniceros cristianos, y quizá de ahí la proliferación en el siglo XV de disposiciones regias, canónicas y concejiles que prohibían a la población cristiana el consumo de carne judiega, así como su venta en las tablas comunes de las carnicerías. En esta línea se encuentra la bula promulgada en el año 1415 por el papa Benedicto XIII —el antipapa Luna-, en la que se de-

* J. RIERA I SANS, "La conflictivitat de l'alimentació dels jueus medievals (segles XII-XV)", pág. 307.

F. SuAREZ, El Fuero Judiego en la España Cristiana, págs. 197-198.

* J. RiERA I SANS, “La conflictivitat de l'alimentació dels jueus medievals (segles XII-XV), pág. 306. 
creta la pena de excomunión general para todo cristiano que comprara a judíos carnes rechazadas por ellos ${ }^{91}$. A lo largo de todo el siglo XV son diversas las ordenanzas concejiles que condenan de forma terminante la venta por parte de los judíos en las tablas comunes de las carnicerías de carne degollada y manipulada por ellos y, especialmente, de la que rechazaban como trifá. En 1420 los paers de Cervera, movidos por las predicaciones de un fraile, reconocian que, en contra de las disposiciones pontificias, permitían que los judíos degollaran públicamente en las carnicerías de la villa, y que

“... quant les carnes son scorchades, meten les sues leges mans dins lo moltó - hovella que haurán degollat, e si trobaran que.Is dits moltó o ovella que haurán degollat es treffà e no casser, lexen aquelles carns per ells manejades e palpades, dients: Menjem-los s'o los cans, car nosaltres no.n volem, e açò en gran injùria e desonor de tota christiantat $"$ 92 .

En consecuencia, los paers prohibían a los cristianos comer las carnes desechadas por judíos, bajo pena de diez sueldos, y a los carniceros cristianos venderlas, bajo pena de veinte sueldos.

En cualquier caso, pese a las constantes prohibiciones y a las condenas que su incumplimiento llevaban aparejadas, todo hace suponer que a lo largo de todo el siglo XV los judíos continuaron dando salida a su carne trifá vendiéndola a cristianos, muy posiblemente a precios inferiores a los habituales. Asi, la documentación inquisitorial de fines del siglo XV y de los primeros decenios del siglo XVI ofrece algunos ejemplos interesantes acerca de este tipo de prácticas que, en definitiva, son también señal evidente de una coexistencia cristiano-judía en los años inmediatamente precedentes a la promulgación del decreto de expulsión general de 1492. El 20 de mayo de 1487 Vellida, judia, mujer de don Judá Salero, declaró ante el tribunal de la Inquisición que en una ocasión había cecinado en su casa unos cuartos traseros de cabrón a Pedro de Alonso Arias, judeoconverso vecino de Segovia, que eran trefés y que, por tanto, no podían ser comidos por judíos; todo hace pensar que, con su declaración, Vellida trataba de exculpar al procesado de la acusación de judaizante que pesaba sobre él ${ }^{93}$. En parecidos términos se expresa don Judá Salero, quien actuó como testigo ante el tribunal de la Inquisición en los procesos promovidos contra algunos judeoconversos, entre ellos contra Pedro de Alonso Arias, afirmando

"F. SuÁrez, El Fuero Judiego en la España Cristiana, págs. 312-313.

צ* J. RIERA I SANS, “La conflictivitat de l'alimentació dels jueus medievals (segles XII-XV)", págs. 309310

A.G.S., Patronato Real, Inquisición, leg. 28/73, fol.. C. CARRETE, Fontes ludaeorum Regni Castellae, vol, Ill, pág. 113. 
«... que Pedro de Alonso Arias conpró de un judío una cabra muerta y degollada del judio porque salió trefé, y rogó al judío, que se llama Santos, que se la cecinase en su cassa, e lo fiço asì ${ }^{94}$.

\subsection{Los edificios públicos de la judería destinados a la venta y distribución de carne y pescado.}

En uso de la autonomía de que disfrutaban para organizar el abastecimiento alimentario de la comunidad hebrea, las aljamas disponían de edificios públicos destinados a la venta de alimentos.

En cuanto entidad jurídica que eran, las aljamas eran propietarias, con frecuencia, de un centro de distribución de alimentos denominado tienda de la aljama o buhonería judiega, cuya explotación era arrendada a un judío o a un cristiano, normalmente por tiempo de un año; salvo circunstancia que aconsejara lo contrario, el arrendamiento se renovaba de forma automática, con una actualización del precio de cesión. Entre las condiciones que se fijan en el contrato de arrendamiento de la tienda de la aljama de la localidad aragonesa de Épila se incluye la obligación de que estuviera permanentemente abastecida de pescado, aceite y queso, entre otros productos, así como la de que sus precios de venta fueran iguales a los de la tienda cristiana ${ }^{95}$.

En algunas aljamas consta documentalmente la existencia de una pescadería judiega. Es éste el caso de Barcelona, en cuyo Call Mayor se localizaba en el año 1381 una pescadería, cerca de la sinagoga mayor ${ }^{96}$.

Las aljamas disponían también de una o varias tabernas, en las que se despachaba el vino judiego o kasher. En su capitulo tercero, las Taqqanoth de Valladolid de 1432 establecen que toda comunidad hebrea que contara con al menos diez cabezas de familia habría de disponer de una taberna de vino kasher, una ordenanza interna debería regular el uso de la taberna y la venta de vino ${ }^{97}$.

Pero, sin duda alguna, entre todos los edificios de la aljama destinados al abastecimiento de alimentos a la comunidad hebrea el más importante era la carnicería, el edificio público más importante de la judería después de la sinagoga y del cementerio.

Ibidem.

9s M.A. MOtis DOLADER, «Articulación y funcionalidad del barrio judio de Épila en el siglo XV. Convivencialidad o segregación", en CARLos BaRRos (ed.), Xudeus e Conversos na Historia. Santiago de Compostela. La Editorial de la Historia, 1994, vol. II, págs. 263-317 (en concreto, págs. 286-287).

46. Archivo Histórico de Protocolos de Barcelona, Bonanat Rimentol, capbreu 1381, fols. 43-44

'Yolanda MORENO KOCH, Fontes ludaeorum Regni Castellae. V. De iure hispano-hebraico. Las Taqqanot de Valladolid de 1432. Un estatuto comunal renovador. Salamanca. Universidad Pontificia de Salamanca. Universidad de Granada, 1987, págs. 65-67. 
En general se considera que para que una carnicería fuera rentable en época bajomedieval debía servir a un mínimo de cincuenta fuegos o familias ${ }^{98}$. Sin embargo, teniendo en cuenta el complejo ritual judío relativo al sacrificio de los animales para el consumo humano (shehitah), toda comunidad hebrea de cierta importancia, independientemente del número de sus integrantes, disponía de una carniceria propia a la que, ocasionalmente, acudian también judeoconversos y cristianos viejos. En algunas localidades está documentada, incluso, la existencia de más de una carnicería; en estos casos era frecuente que una de ellas estuviera destinada a judíos pecheros y la otra a judíos francos, como sucedía en Zaragoza y Calatayud ${ }^{99}$.

En algunas localidades la aljama judía no disponía de matadero propio, como sucedía en Molina de Aragón, donde a fines del siglo XV cristianos, judíos y mudéjares compartían una carnicería y un matadero únicos, como se deduce de la confesión que el 18 de agosto de 1492 hizo ante el tribunal de la Inquisición Aldonza Fernández, judeoconversa vecina de esta localidad alcarreña:

"Yten he comido carne de judíos e moros, porque en la carneçería de los christianos, por mandado de las justiçias, los judios arrendadores o físycos degollavan carneros, e lo que sobraba conpravan todos que se açercavan. $E$ asymismo acahesçía de los moros, que toda la carneçería era una" ${ }^{100}$

Sin embargo, las autoridades concejiles no veían, normalmente, con buenos ojos este uso compartido del matadero, como se deduce de las prohibiciones que para ello se dictaron en Elche en $1312^{101}$, en Montblanc en $1321-1322^{102}$, en Palma de Mallorca en $1370^{103}$ y en Valencia en $1403^{104}$; la causa alegada para dictar estas prohibiciones era el temor a que las carnes de los judíos contaminaran las de los cristianos si eran manipuladas por los hebreos.

Jean-Pierre Leguay, La rue au Moyen Äge. Rennes. Ouest France, 1984, pág. 166.

Asunción Blasco MARTinez, La juderia de Zaragoza en el siglo XIV. Zaragoza. Institución Fernando el Católico, 1988, pág. 166.

A.H.N., Inquisición de Toledo, leg. 1930, n. ${ }^{2}$ 13. Enrique CANTERA MONTENEGRO, "Solemninades, ritos y costumbres de los judaizantes de Molina de Aragón a fines de la Edad Media", en Actas del /l Congreso Internacional "Encuentro de las Tres Culturas". Ayuntamiento de Toledo, 1985, págs. 59-88 (en concreto. págs. 76-77).

En 1314 los judios ilicitanos obtuvieron autorización para disponer de una carniceria propia (José Hinojosa Montalvo, "Los judíos en Elche durante la Baja Edad Media". en Homenaje al profesor Juan Torres Fontes. Murcia, 1988, pág. 794).

Con el fin de impedir que la carne que comian los cristianos fuera manipulada por los judios, me. diante dos provisiones reales, y a instancia de los prohombres de la localidad, Jaime II asignaba a los judios de Montblanc una carniceria propia (J. RIERA I SANS, "La conflictivitat de l'alimentació dels jueus medievals (segles XII-XV)", pág. 307).

Antonio Pons, Los judios del Reino de Mallorca durante los siglos XIII y XIV. Palma de Mallorca. Miguel Font Editor, 1984, 2 vols. (en concreto, vol. II, pág. 51)

"1,4 M.A. MOTis DOLADER, "Régimen alimentario de las comunidades judias y conversas en la Corona de Aragón en la Edad Media", pág. 287 
Un excelente modelo para conocer el funcionamiento de una carniceria hispanojudía de época bajomedieval es el de Zaragoza, pues se conservan unos completos estatutos de la carnicería judía zaragozana de fines del siglo XV, que dio a conocer, hace ya tres decenios, José Luis Lacave ${ }^{105}$.

Según estos estatutos, la carnicería judía de Zaragoza se organizaba en dos tiendas o tablas de cortar y despachar la carne. Sin embargo, consta documentalmente que a fines del siglo XV la carne kasher se despachaba habitualmente en seis tiendas, lo que invita a pensar que los arrendadores de la sisa de la carne judiega se veían obligados a alquilar otras cuatro tiendas, lo que da buena idea de la magnitud de esta comunidad; incluso, en el tránsito del siglo XIV al XV la carnicería judía zaragozana había llegado a disponer de hasta nueve tiendas ${ }^{106}$. Los estatutos de la carniceria judía zaragozana hacen referencia, asimismo, a dos corrales: el "corral de los bueyes", de mayor tamaño, y otro más pequeño en el que se almacenaban los desperdicios.

La sisa o impuesto sobre el consumo de la carne -en ocasiones denominada tasa de la shehitah - constituía un recurso de gran importancia en orden al mantenimiento de las instituciones socio-religiosas y caritativas de las aljamas. El arrendamiento de la sisa tenía lugar en subasta pública, de forma que la aljama percibía del arrendador una cantidad fija por el monto global correspondiente a la sisa de un año; esta cantidad era pagada al clavario o tesorero de la aljama en plazos pagaderos cada quince días. El arrendador, que era autorizado a percibir de los compradores cinco dineros por cada libra de carne, había de procurar luego que se vendiera la mayor cantidad posible de carne, no sólo para recuperar el dinero adelantado por el arrendamiento, sino también para obtener un beneficio. En cualquier caso, y como garantía para la aljama, el arrendador debía presentar fiadores conocidos y abonados, y comprometerse a permanecer bajo la sujeción del comisario de la aljama para cualquier litigio que pudiera surgir en relación con la interpretación de los estatutos.

Para su adecuado funcionamiento, toda carnicería disponía de diversos oficiales -principalmente, el shoet o matarife y el bodeq o shomer, encargado de supervisar que el sacrificio del animal se hiciera con arreglo a las prescripciones de la shehitah-, cuyo salario corría a cargo del arrendador de la sisa, quien también debía hacer frente a los derechos que pudieran corresponder a las autoridades concejiles. Los carniceros -o qassab-, encargados de expender la carne, debian jurar que respetarian escrupulosamente los estatutos de la carnicería, lo que hace pensar que pudieran tener parte en el negocio o que llegaran a un acuerdo económico con el arrendador de la sisa.

- José Luis Lacave RIAÑo "La carniceria de la aljama zaragozana a fines del siglo XV", en Sefarad. XXXV (1975), págs. 3-36.

A. Blasco, La judería de Zaragoza en ei siglo XIV. pág. 169. 
Las aljamas judías procuraban reglamentar de forma minuciosa los múltiples aspectos relativos a la venta de la carne, como los precios, las condiciones que debía reunir la carnicería, la prohibición de introducir carne procedente de otras localidades mientras existieran existencias de la propia localidad, etc.

El primer capítulo de los estatutos de la carnicería zaragozana se refiere por extenso al complejo tema de los precios de venta de la carne. En él se fijan los precios distinguiendo entre los distintos animales, insistiéndose en que dichos precios son siempre sobre la base de que la carne esté totalmente deshuesada. Los precios se fijarian para todo el año, y para su elevación sería imprescindible una autorización expresa por parte del comisario y de los adelantados de la aljama. Asimismo se establece que sólo en el caso de que en el curso del año las autoridades regias ordenaran una elevación en la sisa real sobre la carne ésta podría repercutirse en el precio de venta.

Por otra parte, el arrendador de la sisa de la carne debía comprometerse a mantener la carnicería judía bien abastecida a lo largo de todo el año, en especial con carne de carnero, que debería poner a la venta todos los días de la semana; esto constituye una señal inequívoca de la importancia que la carne de este animal tenía en la dieta alimentaria de los judíos hispanos en la Baja Edad Media.

En último lugar, y con el fin de garantizar los derechos del arrendador de la carnicería, los estatutos de la carnicería judía zaragozana prohibían que los particulares sacrificaran animales en sus casas, excepto con motivo de la celebración de las fiestas de Pésa $h^{107}$, Purim $^{108}$ o Shavu'ot $^{109}$, o con ocasión de una boda o del nacimiento de un nuevo miembro de la familia, y siempre con consentimiento previo del arrendador de la sisa. Asimismo se prohibía la introducción de carne procedente de otra localidad sin el previo pago al arrendador de la sisa de la cantidad que correspondiera.

Término hebreo que significa, literalmente, "pasar de largo». Es la Pascua, una de las tres festividades mayores del calendario litúrgico hebreo, en la que se conmemora la liberación del pueblo judio de la esclavitud de Egipto. Se celebra durante ocho dias, a partir del día 14 del mes de nisán, en los que está terminantemente prohibido el consumo de cualquier tipo de alimento fermentado. El rito principal de Pésah consiste en el séder, cena ritual de la primera noche de la fiesta, que va acompañada de diversas ceremonias que encierran un profundo significado en relación con la liberación del pueblo hebreo en Egipto.

of Festividad menor del calendario litúrgico hebreo, en la que se conmemora la liberación de los judíos en la antigua Persia. Se celebra el dia 14 del mes de adar, en medio de una alegría generalizada, que se expresa en los banquetes que congregan a las familias judias, asi como en los cánticos y en las danzas que los acompañan.

1.9 Término hebreo que significa, literalmente, "siete semanas", con el que se designa a una de las tres festividades mayores del calendario litúrgico judio. Se celebra el día 6 del mes de siván, cincuenta dias después de Pésah. Si en sus origenes era una fiesta agrícola, la fiesta de las primicias, tras la destrucción del segundo Templo de Jerusalén (70 d.C.) se transformó en una fiesta de contenido histórico en la que se rememora la revelación de la Ley en el Monte Sinai. La alegria por la celebración de esta fiesta se expresa en un banquete familiar y en la decoración de la casa con adornos diversos. 
En definitiva, los estatutos de la carnicería judía de Zaragoza regulaban minuciosamente las más diversas cuestiones relativas a la venta de la carne, constituyendo un excelente ejemplo acerca de la organización y funcionamiento de este servicio público, absolutamente fundamental en la vida de toda comunidad judía de época medieval.

\section{A MODO DE CONCLUSIÓN.}

Además de la prioritaria finalidad subsistencial que la alimentación ha tenido siempre, en todo tiempo y lugar, a lo largo de la Edad Media, y hasta tiempos prácticamente actuales, la mesa constituía también el eje en torno al que gravitaba buena parte de las relaciones familiares y comunitarias de la minoría hebrea, contribuyendo de forma determinante al reforzamiento de los vínculos de solidaridad familiar y grupal. La celebración de las principales festividades del calendario litúrgico judio, y los banquetes con ocasión de nacimientos y bodas, reunían a familiares y amigos quienes, de este modo, sentían más próximo el calor de la familia y de la comunidad de creyentes. Asimismo estas celebraciones gastronómicas, marcadas habitualmente por un fuerte simbolismo religioso, permitían a los individuos y a las familias judias profundizar en el sentimiento de singularidad con relación a la sociedad mayoritaria en la que se insertaban, aspecto éste de importancia fundamental para todo colectivo minoritario en orden a evitar su disolución en el seno del grupo mayoritario.

En último término, el estudio de los hábitos alimentarios de la comunidad hebrea -en el caso concreto que nos ocupa en relación con la carne y el pescado- ofrece siempre una información de enorme interés no sólo para el estudio de la minoría judía en sí, sino también para profundizar en el conocimiento de sus relaciones con los restantes colectivos socio-religiosos, ponierido de manifiesto las profundas interconexiones culturales y folclóricas que en época medieval, y a lo largo de los tiempos modernos, existieron entre judios, cristianos y musulmanes. 